Article

\title{
Synthesis and Characterization of 1,10-Phenanthroline-mono- $N$-oxides
}

\author{
Ferenc Najóczki ${ }^{1,2} \mathbb{D}^{D}$, Mária Szabó ${ }^{1}$, Norbert Lihi ${ }^{1,3}$, Antal Udvardy 4 (D) and István Fábián $1,3, *$ (D) \\ 1 Department of Inorganic and Analytical Chemistry, University of Debrecen, Egyetem tér 1, \\ H-4032 Debrecen, Hungary; najoczki.ferenc@science.unideb.hu (F.N.); szabo.maria@science.unideb.hu (M.S.); \\ lihi.norbert@science.unideb.hu (N.L.) \\ 2 Doctoral School of Chemistry, University of Debrecen, Egyetem tér 1, H-4032 Debrecen, Hungary \\ 3 MTA-DE Homogeneous Catalysis and Reaction Mechanisms Research Group, University of Debrecen, \\ Egyetem tér 1, H-4032 Debrecen, Hungary \\ 4 Department of Physical Chemistry, University of Debrecen, Egyetem tér 1, H-4032 Debrecen, Hungary; \\ udvardya@unideb.hu \\ * Correspondence: ifabian@science.unideb.hu; Tel.: +36-52-512-900 (ext. 22378); Fax: +36-52-518-660
}

Citation: Najóczki, F.; Szabó, M.; Lihi, N.; Udvardy, A.; Fábián, I. Synthesis and Characterization of 1,10-Phenanthroline-mono- $N$-oxides. Molecules 2021, 26, 3632. https:// doi.org/10.3390/molecules26123632

Academic Editor: José Luis de Paz

Received: 21 May 2021

Accepted: 10 June 2021

Published: 14 June 2021

Publisher's Note: MDPI stays neutral with regard to jurisdictional claims in published maps and institutional affiliations.

Copyright: (c) 2021 by the authors. Licensee MDPI, Basel, Switzerland. This article is an open access article distributed under the terms and conditions of the Creative Commons Attribution (CC BY) license (https:// creativecommons.org/licenses/by/ $4.0 /)$.

\begin{abstract}
N$-oxides of $N$-heteroaromatic compounds find widespread applications in various fields of chemistry. Although the strictly planar aromatic structure of 1,10-phenanthroline (phen) is expected to induce unique features of the corresponding $N$-oxides, so far the potential of these compounds has not been explored. In fact, appropriate procedure has not been reported for synthesizing these derivatives of phen. Now, we provide a straightforward method for the synthesis of a series of mono- $N$-oxides of 1,10-phenanthrolines. The parent compounds were oxidized by a green oxidant, peroxomonosulfate ion in acidic aqueous solution. The products were obtained in high quality and at good to excellent yields. A systematic study reveals a clear-cut correlation between the basicity of the compounds and the electronic effects of the substituents on the aromatic ring. The UV spectra of these compounds were predicted by DFT calculations at the TD-DFT/TPSSh/def2-TZVP level of theory.
\end{abstract}

Keywords: density functional calculation; N-oxide; oxidation; peroxomonosulfate ion; X-ray diffraction

\section{Introduction}

$\mathrm{N}$-oxides of heterocycles are of great importance due to their widespread applicability, including, but not limited to, manufacturing chirality chemosensors [1], oxidizing agents in annulation reactions [2], intramolecular oxidants in Baeyer-Villiger reaction of ketones [3], directing group and source of oxygen atom in sulfonylation reactions [4], phase-transfer catalysts in enantioselective transformations [5], starting materials in $C-C$ bond forming processes [6-9], or in the synthesis of 2-aminopyridines [10] and $N$-azine sulfoximines [11]. Recently published papers have discussed the cycloaddition reactions of $N$-oxides [12], their photochemistry [13,14] and their applications in organocatalysis [15-17]. Within this family of compounds, only limited information is available on 1,10-phenanthroline-1-Noxide (phenO) and its derivatives. A few metal complexes of phenO have been synthesized in solid phase since the 1970s, but the detailed characterization of these compounds is not available [18-28]. Recent results show that platinum(II) complexes of phenO have broad potential as oxygen atom transfer reagents because of their ability to activate the $\mathrm{N}-\mathrm{O}$ bond [29].

The $N$-oxidation of 1,10-phenanthroline (phen) has been studied since the 1940s [30]. It was shown that the use of $\mathrm{H}_{2} \mathrm{O}_{2}$ or its derivatives such as $\mathrm{H}_{2} \mathrm{O}_{2}$ in glacial acetic acid (where the active oxidant is most likely peracetic acid) [31-33] or the adduct between $\mathrm{H}_{2} \mathrm{O}_{2}$ and urea (known as UHP) [34] results in phenO. Earlier, an unsuccessful effort was made to obtain phen $\mathrm{O}_{2}$ by refluxing phen for 2 days in $90 \%$ hydrogen peroxide, glacial acetic acid, 
and concentrated sulfuric acid, where Caro's acid (peroxomonosulfuric acid, $\mathrm{H}_{2} \mathrm{SO}_{5}$ ) is the dominant form of the oxidant [33]. A plausible reason behind the fruitless synthesis under such conditions was the use of inappropriate $\mathrm{pH}$. Up to now, two successful methods have been reported in the literature that yield the di- $\mathrm{N}$-oxide of phen $\left(\mathrm{phenO}_{2}\right)$ : one applies elemental fluorine as an oxidant [35], while the other one uses peroxomonosulfate ion (PMS) in aqueous solution under neutral conditions [36].

Recently, we have shown that the $\mathrm{pH}$ plays an important role in the kinetics of the oxidation of phen and its derivatives by PMS [36,37]. In acidic solutions, the relatively slow oxidation reaction follows net second-order kinetics with 1:1 stoichiometry of the reactants, and the reaction yields only mono- $N$-oxide. The sluggishness of the reaction is due to the protonation of the substrate which hinders the oxidative attack on the nitrogen atoms. Under such conditions, the product is also present in protonated form $\left(\mathrm{HphenO}^{+}\right)$featuring a strong intramolecular hydrogen bond. This prevents the oxidation of the second nitrogen atom, i.e., the formation of the corresponding di- $\mathrm{N}$-oxide. This $\mathrm{pH}$-dependence offers a simple way for the synthesis of mono- $\mathrm{N}$-oxides of phen derivatives under relatively mild conditions and without the interference of the formation of the di- $N$-oxides.

Apart from phenO, only the preparation of 2,9-dimethyl-1,10-phenanthroline-1- $N$ oxide (DMPO) was reported earlier in the literature [38]. Now, we report the synthesis and full characterization of a series of $N$-oxides obtained from phen derivatives (Figure 1 , Table 1). The rigid $N$-heteroaromatic ring structure is a specific feature of these compounds which may lead the way for unique applications in the fields mentioned above. The main objective of this study is to prepare the corresponding $N$-oxides for further studies to explore these possibilities.

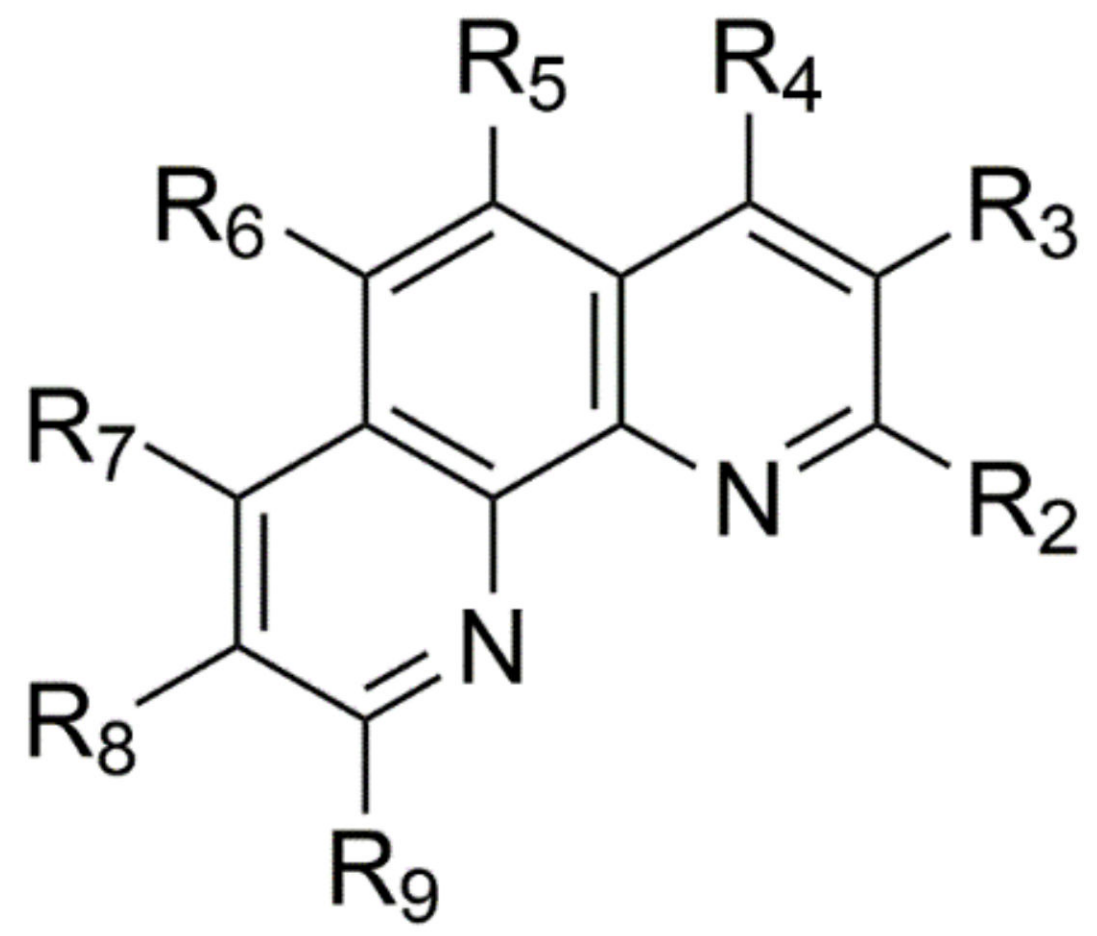

Figure 1. The general structural formula of the substrate. The substituents of the individual derivatives are listed in Table 1. 
Table 1. The phen derivatives used in this study.

\begin{tabular}{cccccccccc}
\hline Name & Abbrev. & $\mathbf{R}_{\mathbf{2}}$ & $\mathbf{R}_{\mathbf{3}}$ & $\mathbf{R}_{\mathbf{4}}$ & $\mathbf{R}_{\mathbf{5}}$ & $\mathbf{R}_{\mathbf{6}}$ & $\mathbf{R}_{\mathbf{7}}$ & $\mathbf{R}_{\mathbf{8}}$ & $\mathbf{R}_{\mathbf{9}}$ \\
\hline 1,10-phenanthroline & phen & $\mathrm{H}$ & $\mathrm{H}$ & $\mathrm{H}$ & $\mathrm{H}$ & $\mathrm{H}$ & $\mathrm{H}$ & $\mathrm{H}$ & $\mathrm{H}$ \\
4-methyl-1,10-phenanthroline & $4 \mathrm{MP}$ & $\mathrm{H}$ & $\mathrm{H}$ & $\mathrm{Me}$ & $\mathrm{H}$ & $\mathrm{H}$ & $\mathrm{H}$ & $\mathrm{H}$ & $\mathrm{H}$ \\
5-methyl-1,10-phenanthroline & $5 \mathrm{MP}$ & $\mathrm{H}$ & $\mathrm{H}$ & $\mathrm{H}$ & $\mathrm{Me}$ & $\mathrm{H}$ & $\mathrm{H}$ & $\mathrm{H}$ & $\mathrm{H}$ \\
2,9-dimethyl-1,10-phenanthroline & $\mathrm{DMP}$ & $\mathrm{Me}$ & $\mathrm{H}$ & $\mathrm{H}$ & $\mathrm{H}$ & $\mathrm{H}$ & $\mathrm{H}$ & $\mathrm{H}$ & $\mathrm{Me}$ \\
3,4,7,8-tetramethyl-1,10- & $\mathrm{TMP}$ & $\mathrm{H}$ & $\mathrm{Me}$ & $\mathrm{Me}$ & $\mathrm{H}$ & $\mathrm{H}$ & $\mathrm{Me}$ & $\mathrm{Me}$ & $\mathrm{H}$ \\
phenanthroline & $5 \mathrm{NP}$ & $\mathrm{H}$ & $\mathrm{H}$ & $\mathrm{H}$ & $\mathrm{NO}_{2}$ & $\mathrm{H}$ & $\mathrm{H}$ & $\mathrm{H}$ & $\mathrm{H}$ \\
5-nitro-1,10-phenanthroline & $5 \mathrm{CP}$ & $\mathrm{H}$ & $\mathrm{H}$ & $\mathrm{H}$ & $\mathrm{Cl}$ & $\mathrm{H}$ & $\mathrm{H}$ & $\mathrm{H}$ & $\mathrm{H}$ \\
5-chloro-1,10-phenanthroline & & & & & & & &
\end{tabular}

\section{Results and Discussion}

\subsection{Synthesis of the $N$-oxides}

On the basis of our earlier kinetic results [36,37], we developed a synthetic method to obtain solely the mono- $N$-oxides of 1,10-phenanthroline derivatives by avoiding the further oxidation of the primary products. We have shown earlier that the rate of the oxidation increases significantly by increasing the $\mathrm{pH}$, and various oxidation products are formed in the excess of Oxone at neutral $\mathrm{pH}$. Furthermore, phen is not converted solely into phenO, even when one equivalent of PMS is used under neutral conditions [36]. The spent reaction mixture contains approximately $10-15 \%$ of phen, $70-75 \%$ of phenO and $10-15 \%$ of $\mathrm{phenO}_{2}$. Thus, the most important prerequisite of the selective synthesis of phenO is the use of appropriate $\mathrm{pH}$, i.e., as long as the mono- $\mathrm{N}$-oxide is in the protonated form, the di- $\mathrm{N}$-oxidation does not take place.

Oxone itself is acidic due to its $\mathrm{KHSO}_{4}$ content, but $\sim 0.015 \mathrm{M} \mathrm{H}_{2} \mathrm{SO}_{4}$ was also added to the reaction mixtures to provide required acidic conditions for controlled oxidation. Oxone was used in less than $10 \%$ excess over the substrate. While increased concentration of the oxidant would have reduced the reaction time significantly, such conditions were not used in order to avoid complications during further steps of the preparative process. A systematic study of the temperature dependence of the oxidation rates revealed that the reactions proceed more than an order of magnitude faster above $60^{\circ} \mathrm{C}$ than at room temperature. However, it was reported earlier that temperatures above $70^{\circ} \mathrm{C}$ may result in the opening of the middle ring of the substrate [38]. Thus, the oxidation was performed at $60{ }^{\circ} \mathrm{C}$ by strictly controlling the temperature. The progress of the reaction was monitored by analyzing the reaction mixture for the substrate and the product by the HPLC method. In the HPLC chromatograms of the spent reaction mixtures, the characteristic peak of the substrate was absent, and only one intense new peak appeared, which was assigned to the product (Figure S1, in the Supplementary Materials). The quantitative (more than 99 \%) conversion of the substrates into the corresponding mono- $N$-oxides was also confirmed by conventional $1 \mathrm{D}^{1} \mathrm{H}$ and ${ }^{13} \mathrm{C}$ NMR measurements, 2D correlation $\left({ }^{1} \mathrm{H}-{ }^{1} \mathrm{H}\right.$ and $\left.{ }^{1} \mathrm{H}_{-}{ }^{13} \mathrm{C}\right)$ techniques, and mass spectrometry (Figures S2-S58). The chemical shifts are listed in the Supplementary Materials. The results are in excellent agreement with the data reported for phenO [29] and DMPO [38].

The time required for complete consumption of the substrate varied between 2 and $38 \mathrm{~h}$ (Table 2) depending on the substituents on phen. In order to obtain solid products, an aliquot of $2 \mathrm{M} \mathrm{NaOH}$ solution was added to the reaction mixture to set the $\mathrm{pH}$ between 9 and 10. Due to the $\mathrm{pH}$ change, the color of the solution turned into deep orange. Subsequently, the reaction mixture was extracted with appropriate amount of chloroform. Finally, the organic solvent was removed in a vacuum rotational evaporator. The color of the final products varied between yellow and purple depending on the substituent. The hydration of these dry materials led to a brownish color change. 
Table 2. Synthesis of 1,10-phenanthroline-mono- $N$-oxides.

\begin{tabular}{ccc}
\hline Product $^{\mathbf{a}}$ & Reaction Time (h) & Yield (\%) \\
\hline phenO & 3.5 & 86.6 \\
DMPO & 10.0 & 91.2 \\
TMPO & 2.0 & 88.1 \\
$5 \mathrm{MPO}$ and 6MPO & 3.5 & 79.5 \\
$5 \mathrm{NPO}$ and 6NPO & 9.5 & 92.1 \\
$5 \mathrm{CPO}$ and 6CPO & 38.0 & 87.2 \\
$4 \mathrm{MPO}$ and 7MPO & 3.5 & 82.5 \\
\hline
\end{tabular}

a: phenO, DMPO, TMPO, 5MPO, $6 \mathrm{MPO}, 5 \mathrm{NPO}, 6 \mathrm{NPO}, 5 \mathrm{CPO}, 6 \mathrm{CPO}, 4 \mathrm{MPO}$ and $7 \mathrm{MPO}$ stand for the 1,10phenanthroline-, 2,9-dimethyl-, 3,4,7,8-tetramethyl-, 5-methyl-, 6-methyl-, 5-nitro-, 6-nitro-, 5-chloro-, 6-chloro-, 4-methyl- and 7-methyl-1,10-phenanthroline-1-N-oxide, respectively.

The desired products were obtained from good to excellent yields (Table 2). When isomer $\mathrm{N}$-oxides are formed, the yield of the product is given before separation of the isomers. As indicated in our previous paper [37], the 5MPO-6MPO, 5NPO-6NPO and $5 \mathrm{CPO}-6 \mathrm{CPO}$ isomer pairs form in about a 1:1 ratio, while 3 times more $4 \mathrm{MPO}$ is produced than $7 \mathrm{MPO}$ in the oxidation of $4 \mathrm{MP}$. Finally, the isomers were separated by preparative HPLC method.

\subsection{The Acid Dissociation Constants of Substituted Mono-N-oxide Derivatives}

Proper characterization of the acid-base properties of the synthetized $N$-heteroaromatic compounds are of great significance for various reasons. These features have crucial implications in the coordination and redox chemistry of these compounds, as well as in their practical applications. Furthermore, the $\mathrm{p} K_{\mathrm{a}}$-s of these compounds are also important regarding the synthesis of mono- $\mathrm{N}$-oxides, because they need to be in protonated form during the oxidation of the parent compounds in order to avoid the formation of further oxidation products. In contrast, the sufficient extraction of the products from aqueous solution by organic solvents requires that they are present mainly in deprotonated (neutral) form.

The acid dissociation constants of the phenanthrolinium ion (Equation (1)) of phenO-s were determined by one of the methods discussed in the subsequent paragraphs.

$$
\mathrm{HL}^{+} \rightleftharpoons \mathrm{L}+\mathrm{H}^{+} \mathrm{K}_{\mathrm{a}}=\frac{[\mathrm{L}]\left[\mathrm{H}^{+}\right]}{\left[\mathrm{LH}^{+}\right]}
$$

where $\mathrm{L}$ denotes the $\mathrm{N}$-oxide.

When the solubility of the substrate was sufficiently high, standard pH-potentiometric titration was performed as described earlier [39]. The relatively small solubility of TMPO and $\mathrm{DMPO}$ at $25.0^{\circ} \mathrm{C}$ prevented the use of $\mathrm{pH}$-potentiometric titration, and a combined $\mathrm{pH}$-potentiometric and spectrophotometric method was used, where the UV-Vis spectra of the samples were recorded as a function of $\mathrm{pH}$ (Figure 2) [40]. 

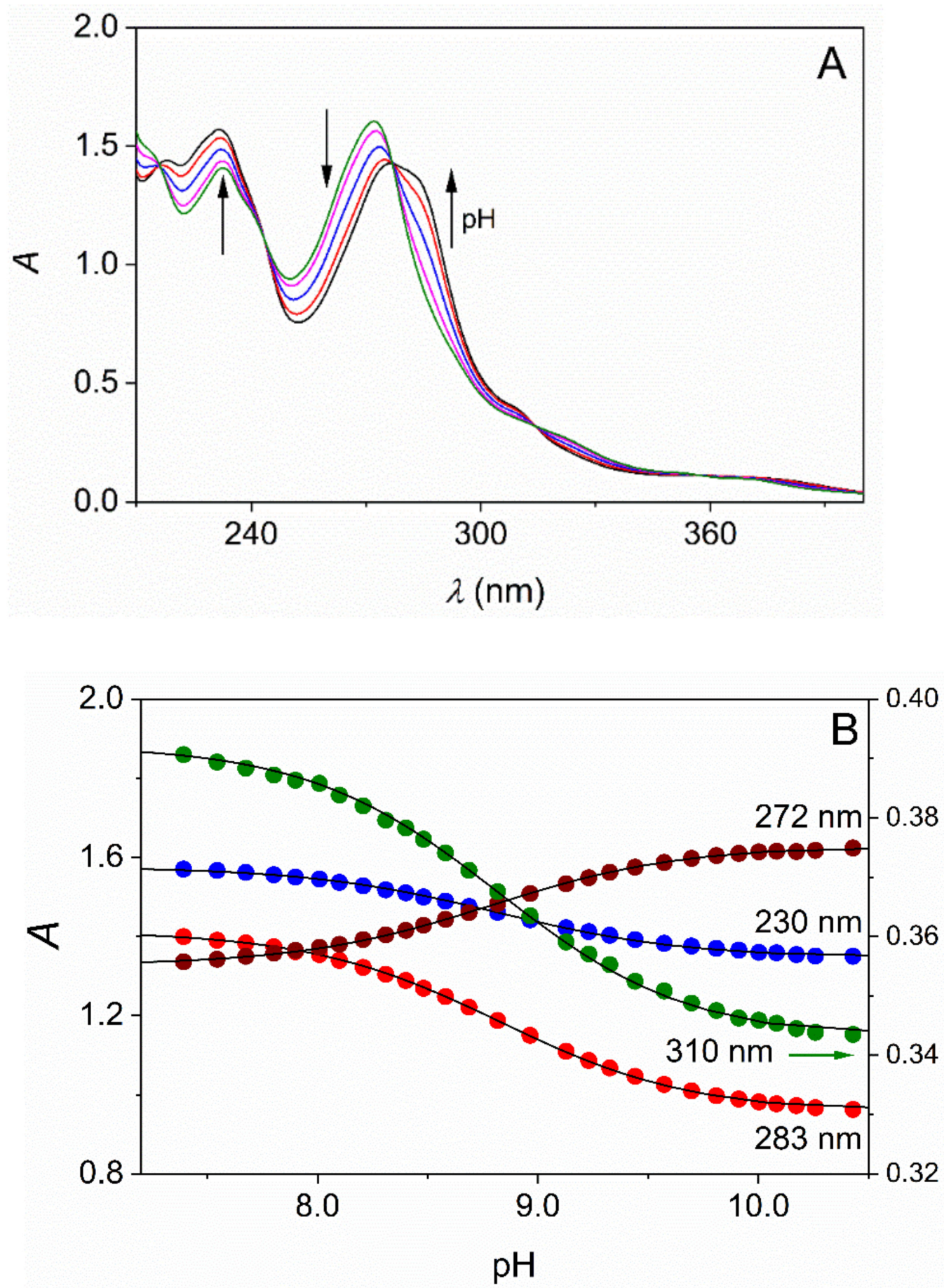

Figure 2. Representative pH-dependent spectra (A) and the absorbance at selected wavelengths (B) as a function of $\mathrm{pH}$ in aqueous solution of DMPO. [DMPO]tot $=0.45 \mathrm{mM}, \mathrm{I}=1.00 \mathrm{M}(\mathrm{NaCl})$, $\mathrm{T}=25.0^{\circ} \mathrm{C}$, path length $1.000 \mathrm{~cm}$. The arrows indicate the absorbance change upon the increase of the $\mathrm{pH}(\mathbf{A})$. The results of the simultaneous fit of the absorbance at the selected wavelengths to Equation (2) are shown as solid curves (B). 
The compounds reported here typically feature intense absorption bands in the UV region with $\varepsilon=20,000-30,000 \mathrm{M}^{-1} \mathrm{~cm}^{-1}$. Thus, reliable spectrophotometric measurements are feasible in their dilute solutions at concentration levels as low as $\sim 10-100 \mu \mathrm{M}$. Acidified solutions of $\mathrm{L}$ (ionic strength is set to the desired value) were titrated with standardized $\mathrm{NaOH}$ solution and the $\mathrm{pH}$ and the spectra were recorded. The absorbance data at $4-5$ wavelengths were fitted simultaneously to Equation (2) (Figure 2).

$$
A=\frac{\varepsilon_{\mathrm{HL}}\left[\mathrm{H}^{+}\right]+\varepsilon_{\mathrm{L}} K_{\mathrm{a}}}{\left[\mathrm{H}^{+}\right]+K_{\mathrm{a}}} c_{\text {tot }}
$$

where $A$ is the absorbance measured at a given $[\mathrm{H}]^{+}$and wavelength $(\lambda), \varepsilon_{\mathrm{HL}}$ and $\varepsilon_{\mathrm{L}}$ are the molar absorption coefficients for the protonated and deprotonated forms at $\lambda, K_{\mathrm{a}}$ is the acid dissociation constant and $c_{\text {tot }}$ is the analytical concentration of the substrate.

In several cases, the $\mathrm{N}$-oxidation of the substrate yields structural isomers of very similar basicity. The $\mathrm{pH}$-potentiometric and spectrophotometric methods are not suitable to simultaneously determine the corresponding $\mathrm{p} \mathrm{K}_{\mathrm{a}}$-s without separation of these compounds because the protolytic equilibria strongly overlap. In such a situation, ${ }^{1} \mathrm{H}$ NMR spectra were recorded in the solutions of the unseparated isomers. The chemical shifts of the NMR peaks of each isomer were selectively followed as a function of $\mathrm{pH}$ and used for calculating the $\mathrm{p} K_{\mathrm{a}}-\mathrm{s}$. As an example, the $\mathrm{pH}$ dependent ${ }^{1} \mathrm{H}$ NMR spectra of the $4 \mathrm{MPO}$ $7 \mathrm{MPO}$ system (the isomer oxidation products of 4MP) are shown in Figure 3A. Each isomer has 7 chemically inequivalent aromatic and 3 equivalent methyl protons. The assignment of the aromatic proton peaks corresponds to Figure 1. (pH-dependent ${ }^{1} \mathrm{H}$ NMR spectra of the 5CPO-6CPO, 5NPO-6NPO, 5MPO-6MPO pairs are reported in Figures S59-S61.). The goodness of the fit is demonstrated in Figure 3B, where the relative chemical shift (Equation (3)) is plotted as a function of $\mathrm{pH}$.

$$
\delta_{\text {rel }}=\frac{\delta_{\mathrm{pH}^{-}} \delta_{\mathrm{L}}}{\delta_{\mathrm{HL}}-\delta_{\mathrm{L}}}
$$

Some of the peaks overlap at a specific $\mathrm{pH}$ and cannot be used for calculating the $\mathrm{p} K_{\mathrm{a}}$-s. Finally, the chemical shifts of three $4 \mathrm{MPO}$ (methyl, A2, A9) peaks, as well as three $7 \mathrm{MPO}$ (methyl, B2, B9) peaks, were fitted simultaneously to Equation (4).

$$
\delta=\frac{\delta_{\mathrm{HL}}[\mathrm{H}]^{+}+\delta_{\mathrm{L}} K_{\mathrm{a}}}{\left[\mathrm{H}^{+}\right]+K_{\mathrm{a}}}
$$

where $\delta$ is the chemical shift measured at a given $\left[\mathrm{H}^{+}\right], \delta_{\mathrm{HL}}$ and $\delta_{\mathrm{L}}$ are the chemical shifts for the protonated and deprotonated forms.

The identical $\mathrm{pH}$ patterns of the chemical shifts of the peaks of the given isomer also corroborate the peak assignments of the ${ }^{1} \mathrm{H}$ NMR spectra.

The calculated $\mathrm{pK} K_{\mathrm{a}}-\mathrm{s}$ are listed in Table 3. Basicity data for phenO-s have not been reported before. 


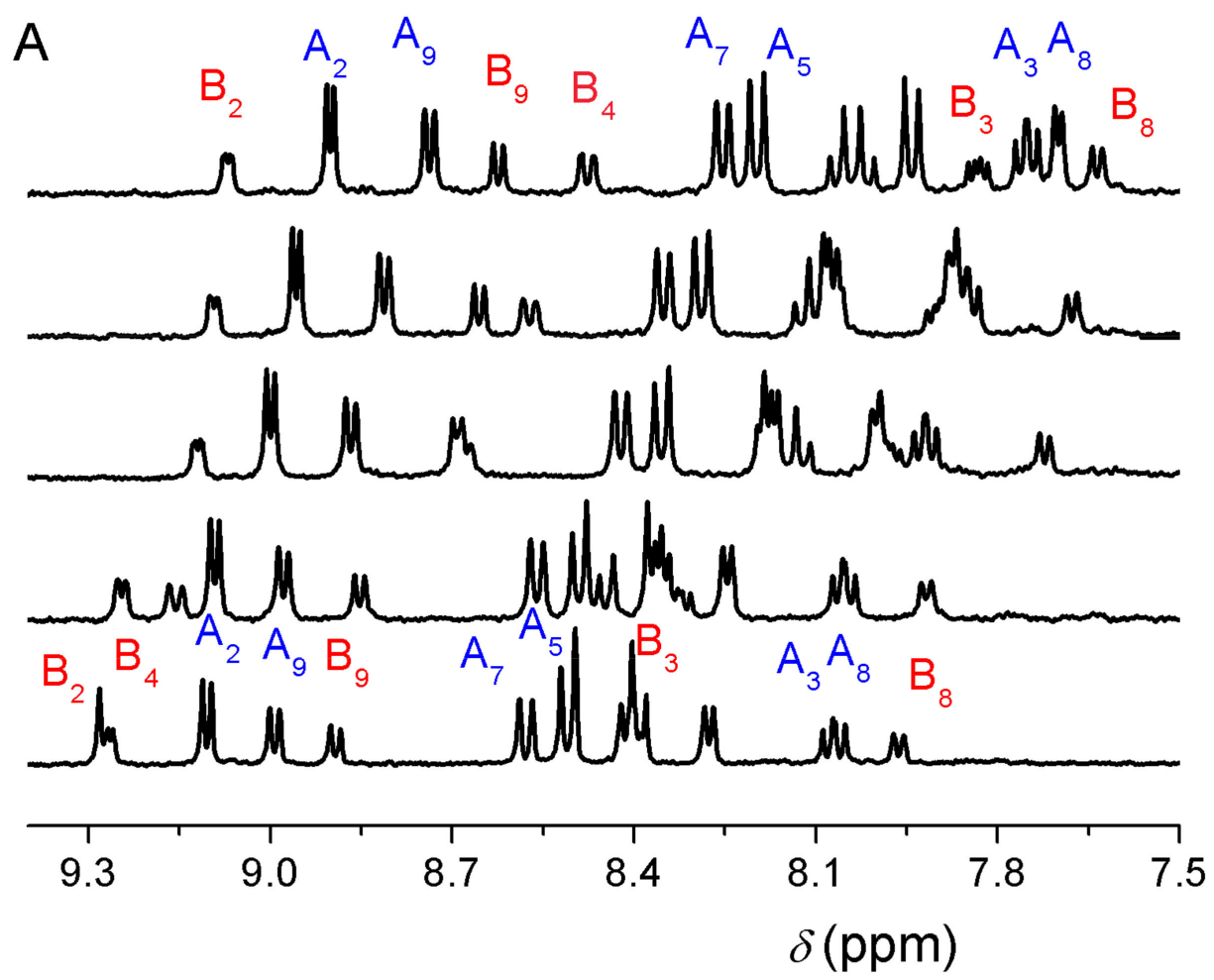

$\mathrm{pH}$

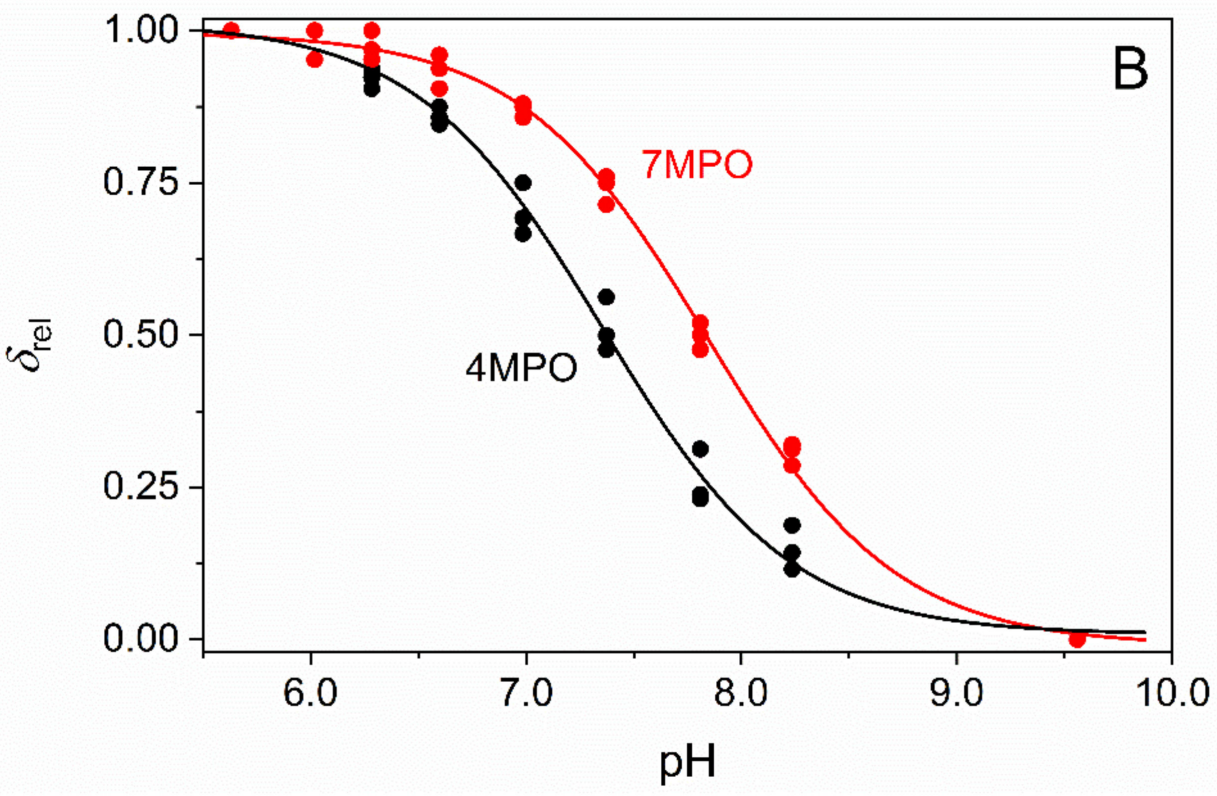

Figure 3. The $\mathrm{pH}$ dependence of the aromatic region of the ${ }^{1} \mathrm{H}-\mathrm{NMR}$ spectra of $4 \mathrm{MPO}(\mathrm{A})$ and $7 \mathrm{MPO}$ (B) in $\mathrm{H}_{2} \mathrm{O}$ (Figure $3 \mathrm{~A}$ ) and the plot of the relative chemical shift, $\delta_{\text {rel }}$, of selected peaks of $4 \mathrm{MPO}$ (methyl, A2, A9) and 7MPO (methyl, B2, B9) (Figure 3B) as a function of $\mathrm{pH}$. The numbering of the peaks corresponds to Figure 1. Only every second spectrum is shown for clarity. The solid lines (4MPO: black, 7MPO: red) are obtained by simultaneously fitting the corresponding chemical shifts to equation 4 . [4MPO+7MPO $]_{\text {tot }}=8.2 \mathrm{mM}, I=0.10 \mathrm{M}, T=25.0^{\circ} \mathrm{C}$. 
Table 3. Acid dissociation constants of the phen derivatives.

\begin{tabular}{|c|c|c|c|}
\hline Compound & $\mathrm{p} K_{\mathrm{a}}$ & Substrate & $\mathrm{p} K_{\mathrm{a}}$ \\
\hline phen & $5.12^{\mathrm{a}}$ & & \\
\hline phenO & $7.10 \pm 0.02^{b}$ & & \\
\hline DMP & $5.96^{\mathrm{a}}$ & & \\
\hline DMPO & $8.83 \pm 0.02^{c}$ & & \\
\hline TMP & $6.53^{\mathrm{a}}$ & & \\
\hline TMPO & $9.03 \pm 0.03^{b}$ & & \\
\hline $5 \mathrm{MP}$ & $5.28^{\mathrm{a}}$ & & \\
\hline $5 \mathrm{MPO}$ & $7.40 \pm 0.02^{\mathrm{d}}$ & $6 \mathrm{MPO}$ & $7.50 \pm 0.03^{d}$ \\
\hline $4 \mathrm{MP}$ & $5.75^{\mathrm{a}}$ & & \\
\hline $4 \mathrm{MPO}$ & $7.36 \pm 0.03^{d}$ & $7 \mathrm{MPO}$ & $7.85 \pm 0.02^{d}$ \\
\hline $5 \mathrm{CP}$ & $4.51^{\mathrm{a}}$ & & \\
\hline $5 \mathrm{CPO}$ & $6.40 \pm 0.02^{\mathrm{d}}$ & $6 \mathrm{CPO}$ & $6.14 \pm 0.03^{d}$ \\
\hline $5 \mathrm{NP}$ & $3.46^{\mathrm{a}}$ & & \\
\hline $5 \mathrm{NPO}$ & $5.41 \pm 0.04^{\mathrm{d}}$ & $6 \mathrm{NPO}$ & $5.27 \pm 0.03^{d}$ \\
\hline
\end{tabular}

a: Data are taken from Ref. [37]; b: by standard pH-potentiometric titration, $T=25.0^{\circ} \mathrm{C}, I=1.00 \mathrm{M}\left(\mathrm{NaNO}_{3}\right)$; c: by combined $\mathrm{pH}$-potentiometric and UV-vis titration, $T=25.0^{\circ} \mathrm{C}, I=1.00 \mathrm{M}(\mathrm{NaCl}) .{ }^{\mathrm{d}}$ : by ${ }^{1} \mathrm{H} \mathrm{NMR}$ titration, $T=25.0^{\circ} \mathrm{C}, I=0.10 \mathrm{M}(\mathrm{NaCl})$.

The comparison of the data in Table 3 reveals that phen and its derivatives are significantly (typically about 1.5 to $2.5 \mathrm{p} K_{\mathrm{a}}$ units) stronger acids than the corresponding mono- $N$-oxides. In our recent study, we reported unequivocal evidence for the formation of a strong intramolecular hydrogen bond in $\mathrm{HphenO}^{+}$where the $\mathrm{NH}^{+}$proton partially bonds to the NO oxygen and a six-membered ring forms [36]. This structure stabilizes the protonated species and reduces the driving force of the acid dissociation.

The interpretation of the trends in the $\mathrm{p} K_{\mathrm{a}}$-s for both sets of the 5-substituted compounds (phen-s and phenO-s) is straightforward when the electronic effects of the substituents are considered. Electron withdrawing groups (EWG); such as $-\mathrm{NO}_{2},-\mathrm{Cl}$, reduce the electron density of the aromatic rings and make the molecule more acidic, while an electron donating group (EDG; methyl in our case) decreases the acid strength compared to the non-substituted molecules (phen and phenO).

The distance of the substituent from the protonation site is also a key factor in these compounds. In the $\mathrm{N}$-oxides, the protonation center is the unoxidized nitrogen atom. The closer of the substituent is to the unoxidized nitrogen atom the bigger its electronic contribution to the $\mathrm{p} K_{\mathrm{a}}$. Pairwise comparison of the acidities of the corresponding derivatives clearly demonstrates this effect: $\mathrm{p} K_{\mathrm{a}}(6 \mathrm{CPO})<\mathrm{p} K_{\mathrm{a}}(5 \mathrm{CPO}) ; \mathrm{p} K_{\mathrm{a}}(6 \mathrm{NPO})<\mathrm{p} K_{\mathrm{a}}(5 \mathrm{NPO})$; and $\mathrm{p} K_{\mathrm{a}}(4 \mathrm{MPO})<\mathrm{p} K_{\mathrm{a}}(5 \mathrm{MPO})<\mathrm{p} K_{\mathrm{a}}(6 \mathrm{MPO})<\mathrm{p} K_{\mathrm{a}}(7 \mathrm{MPO})$.

Finally, the same reasoning is valid when the acidities of the mono-, di- and tetramethyl derivatives are compared. The $\mathrm{p} K_{\mathrm{a}}$ increases in both series when the number of the electron donating methyl groups is increased.

$$
\begin{gathered}
\mathrm{p} K_{\mathrm{a}}(\text { phen })<\mathrm{p} K_{\mathrm{a}}(4 \mathrm{MP}) / \mathrm{p} K_{\mathrm{a}}(5 \mathrm{MP})<\mathrm{p} K_{\mathrm{a}}(\mathrm{DMP})<\mathrm{p} K_{\mathrm{a}}(\mathrm{TMP}) \\
\text { and } \mathrm{p} K_{\mathrm{a}}(\text { phenO })<\mathrm{p} K_{\mathrm{a}}(4 \mathrm{MPO}) / \mathrm{p} K_{\mathrm{a}}(5 \mathrm{MPO})<\mathrm{p} K_{\mathrm{a}}(\mathrm{DMPO})<\mathrm{p} K_{\mathrm{a}}(\mathrm{TMPO})
\end{gathered}
$$

\subsection{X-ray Structures of 1,10-Phenanthroline-1-N-oxide Derivatives}

The structures of three new 1,10-phenanthroline-mono- $\mathrm{N}$-oxide derivatives were analyzed by X-ray diffractometry. Good quality crystals of $5 \mathrm{CPO} \times \mathrm{H}_{2} \mathrm{O}$ and $6 \mathrm{CPO} \times \mathrm{H}_{2} \mathrm{O}$ were obtained from their concentrated non-anhydrous methanolic solutions. Both derivatives crystallize in the monoclinic $P 2{ }_{1} / c$ space group. The corresponding structures are shown in Figures S62-S65 and the most important bond lengths are listed in Table 4 (further crystallographic data are listed in Tables S1-S10, in the Supplementary Materials). 
Table 4. The most important bond lengths $(\AA)$ of $5 \mathrm{CPO} \times \mathrm{H}_{2} \mathrm{O}, 6 \mathrm{CPO} \times \mathrm{H}_{2} \mathrm{O}$ and $6 \mathrm{CPO}$.

\begin{tabular}{cccccc}
\hline & $\mathbf{5 C P O} \times \mathbf{H}_{\mathbf{2}} \mathbf{O}$ & $\mathbf{6 C P O} \times \mathbf{H}_{\mathbf{2}} \mathbf{O}$ & $\mathbf{6 C P O}$ & JAJBAX $^{\mathbf{a}}$ & AZASEB $^{\mathbf{b}}$ \\
\hline $\mathrm{N} 1-\mathrm{O} 1$ & $1.297(4)$ & $1.306(2)$ & $1.284(3)$ & 1.284 & 1.320 \\
$\mathrm{C}-\mathrm{Cl}$ & $1.738(4)$ & $1.745(2)$ & $1.740(2)$ & - & - \\
$\mathrm{O} 1-\mathrm{O} 2 \mathrm{~W}$ & $2.870(4)$ & $2.863(2)$ & - & 2.747 & 2.819 \\
$\mathrm{~N}-\mathrm{O} 2 \mathrm{~W}$ & $3.012(5)$ & $2.979(3)$ & - & 3.479 & 2.836 \\
plate-plate & 3.494 & 3.392 & & 6.667 & 3.358 \\
\hline
\end{tabular}

a 2,9-dimethyl-1,10-phenanthroline-1-N-oxide. Data are taken from Ref. [38]. ${ }^{\text {b } 4,10-p h e n a n t h r o l i n e-4-N-o x i d e . ~}$ Data are taken from Ref. [41]

The $\mathrm{N}-\mathrm{O}$ bond distances in $5 \mathrm{CPO} \times \mathrm{H}_{2} \mathrm{O}$ and $6 \mathrm{CPO} \times \mathrm{H}_{2} \mathrm{O}(1.294(4) \AA, 1.306(2) \AA$, respectively) compare well with the average of $\mathrm{N}-\mathrm{O}$ distances observed in other 1,10phenanthroline-mono- $\mathrm{N}$-oxides. $[38,41]$ The chemical occupancies of the oxygen atoms 1 $(100 \%)$ are consistent with the formation of mono- $\mathrm{N}$-oxides. In both cases, the 15 atoms of the ring system are essentially located in one plane, so the $\mathrm{N}$-oxidation does not lead to the distortion of the planar aromatic structure of the 1,10-phenanthroline backbone. The asymmetric units of the two compounds contain one water molecule as a solvent which links the polar fragments (Figures S66-S69). The organic molecules are layered at a distance of $3.494 \AA$ and $3.392 \AA$, respectively. The parallel packing structures of these compounds are stabilized by the stacking interactions between the aromatic rings and the hydrogen bond network (Tables S4 and S7), as shown in Figure 4.
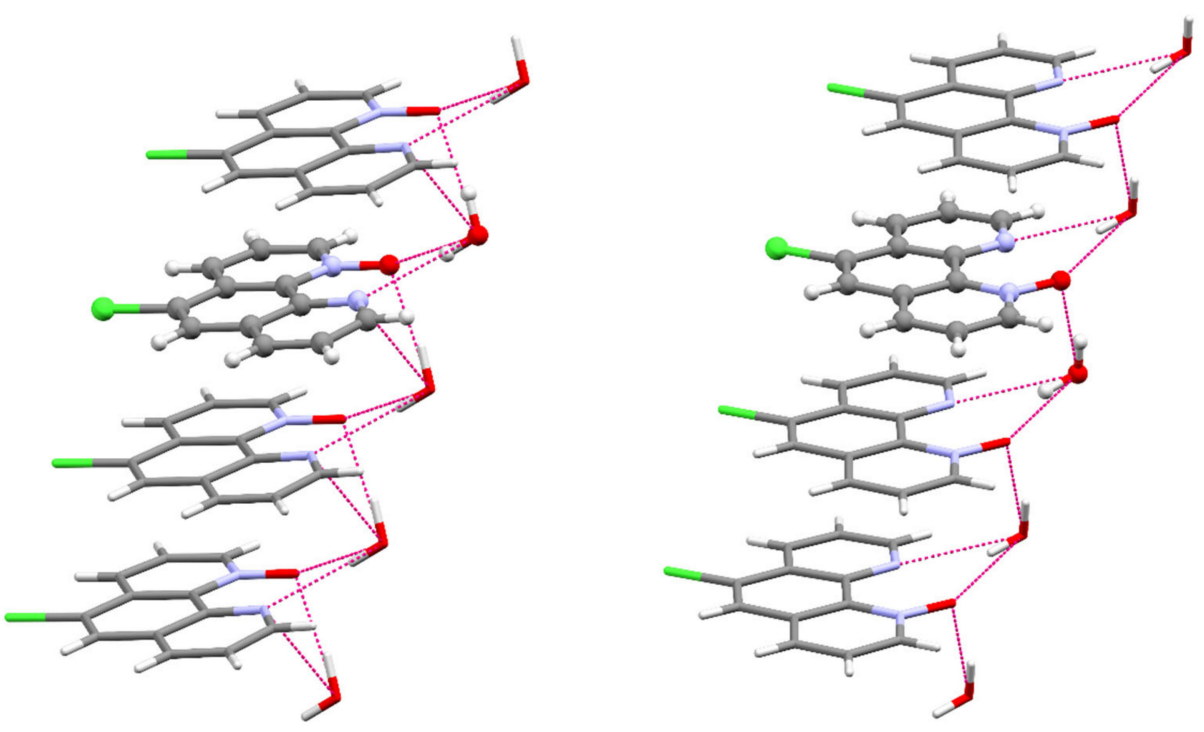

Figure 4. Partial packing view with selected strong hydrogen bonds of $5 \mathrm{CPO} \times \mathrm{H}_{2} \mathrm{O}(\mathbf{l e f t})$ and $6 \mathrm{CPO} \times \mathrm{H}_{2} \mathrm{O}$ (right). The asymmetric unit is given in balls and sticks, and the symmetry-generated part of the compound is given in capped sticks representation.

The 6CPO isomer was also crystallized from chloroform by slow evaporation. In this case, crystals of the orthorhombic $P b c a$ space group were obtained and the asymmetric unit contains only the mono- $\mathrm{N}$-oxide (Figures S64 and S70). As expected, the molecular structures of $6 \mathrm{CPO}$ and $6 \mathrm{CPO} \times \mathrm{H}_{2} \mathrm{O}$ are very similar, although the $\mathrm{N}-\mathrm{O}$ distance is somewhat shorter in 6CPO, 2.284(3) А.

In the case of $5 \mathrm{CPO}, 6 \mathrm{CPO}$ and $6 \mathrm{CPO}$, the calculated distortion angle between N1, $\mathrm{C} 10 \mathrm{~B}, \mathrm{C} 10 \mathrm{~A}$ and $\mathrm{N} 10\left(3.3(5)^{\circ}, 0.9(3)^{\circ}\right.$ and $0.5(3)^{\circ}$, respectively) practically indicates planar geometry.

TMPO was crystallized from non-anhydrous methanolic solution but the diffraction pattern of the crystals is weak. A number of data sets were also collected but in the case of the best sets the $R_{1}$ and $\mathrm{w} R_{2}$ are $9.81 \%$ and $30.92 \%$. While this prevented the determination 
of the exact bond lengths, the connectivities of TMPO are clearly established and are in good agreement with the results of the ${ }^{1} \mathrm{H}-,{ }^{13} \mathrm{C}-\mathrm{NMR}$ data (Figure S65).

TMPO crystallizes in the triclinic crystal system $\bar{P} 1$ space group (as 2,9-dimethyl1,10-phenanthroline-1- $N$-oxide dihydrate [38]), the asymmetric unit contains two mono$\mathrm{N}$-oxides linked by hydrogen network of four water molecules as shown in Figure 5 and Figures S71 and S72.

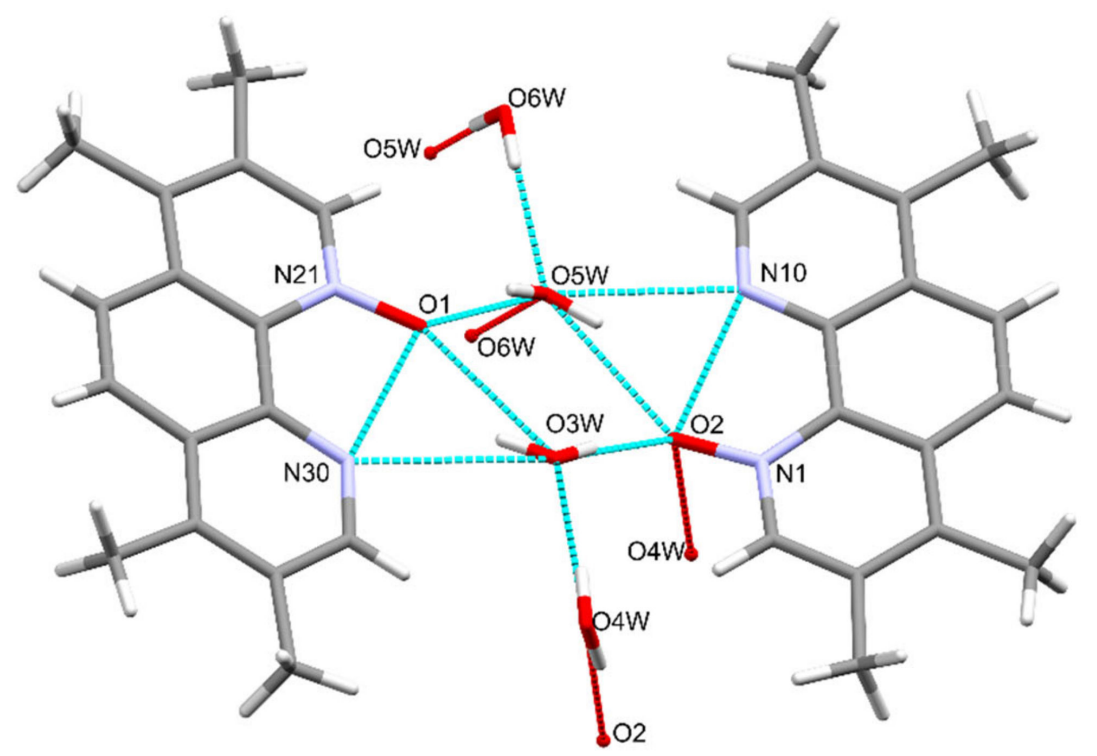

Figure 5. The hydrogen bond interactions between the TMPO and water molecules in $2 \times \mathrm{TMPO} \times 4 \mathrm{H}_{2} \mathrm{O}$.

\subsection{DFT Calculations}

In order to elucidate the electronic absorption spectra and the nature of the electronic transitions of the $\mathrm{N}$-oxides, DFT and TD-DFT calculations were performed (Cartesian coordinates are reported in Tables S11-S21). The comparison of all calculated data (using different functionals) with the experimental spectra revealed that the $10 \%$ exact exchange as represented by the TPSSh functional combined with the triple- $\zeta$ def2-TZVP basis set provides the best prediction of the UV-Vis spectra of these compounds. The experimental and calculated spectra are compared for phenO in Figure 6 (spectra for the other phenO-s are shown in Figures S73-S80).

All spectra exhibit three or four characteristic absorption bands in the 200-400 nm wavelength range (Table S22). The most intensive band at $260-280 \mathrm{~nm}$ features the superposition of two transitions, which are due to a combination of excitations from occupied MOs with $\pi_{\text {arom }}$ character. The absorptions are mainly associated with the $\pi-\pi^{*}$ transitions of the aromatic system and the oscillator strengths are consistent with the experimental values of molar absorptivities. It is also noticeable, that neither the electron donating nor the electron withdrawing groups have significant effects on the energy of the main transition. This also confirms that the excitation is associated with the MOs bearing aromatic character. 


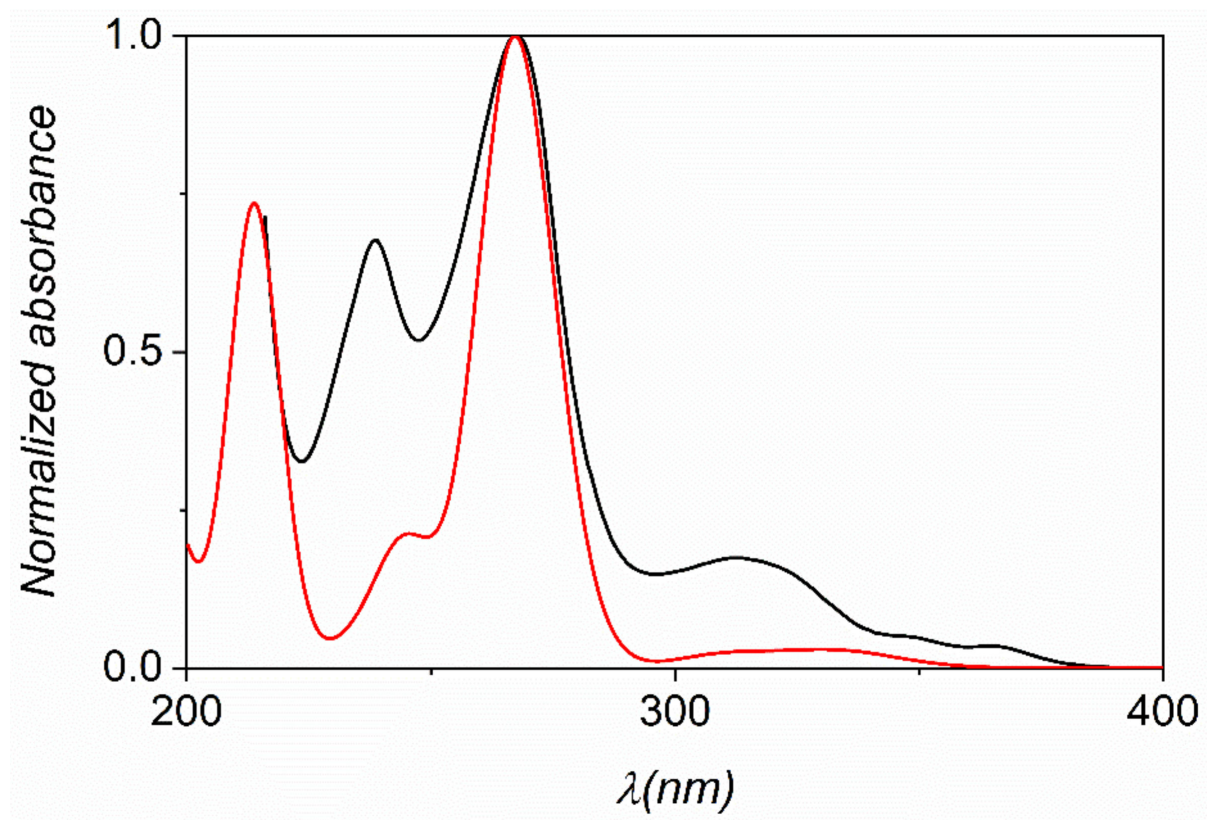

Figure 6. Experimental (black) and calculated (red) UV-Vis spectra of phenO using TDDFT/TPSSh/def2-TZVP level of theory. The presence of water was taken into account by using the PCM approach.

The ${ }^{1} \mathrm{H}$ NMR chemical shifts of phenO were calculated by using the GIAO approach. The experimental and the predicted parameters are in excellent agreement (Figure 7).

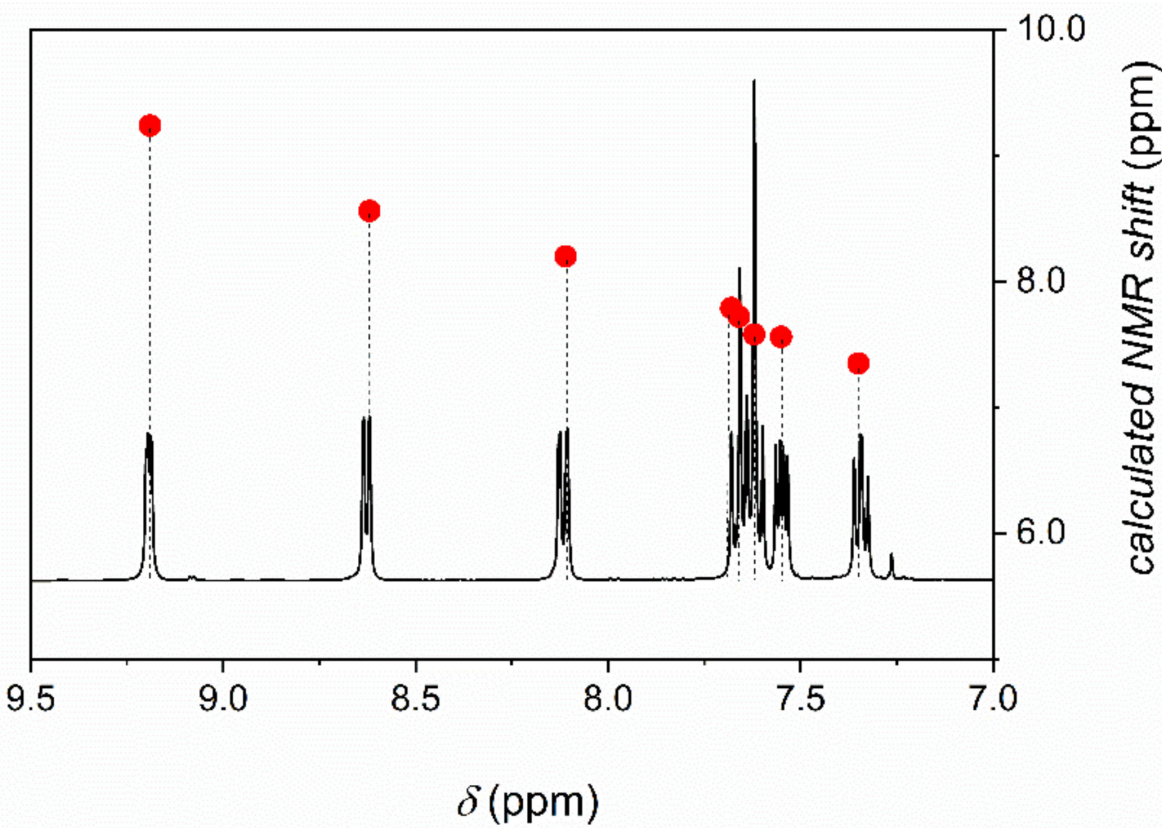

Figure 7. Experimental ${ }^{1} \mathrm{H}$ NMR spectrum and calculated NMR shifts (right axis, $\bullet$ ) of phenO in chloroform. Calculations were performed at B3LYP/6-311+G(2d,p) level of theory. The effect of solvent was taken into account by adopting the PCM model for chloroform.

\section{Materials and Methods}

\subsection{General Information}

All reagents and solvents were of analytical grade and were used as received from commercial sources. All the studied phen-s are commercially available (Aldrich) and were 
used without further purification. Potassium peroxomonosulfate is available as a stable triple salt, a brand named Oxone $\left(2 \mathrm{KHSO}_{5} \cdot \mathrm{KHSO}_{4} \cdot \mathrm{K}_{2} \mathrm{SO}_{4}\right.$, Aldrich) and the solid was added directly to the reaction mixtures during the synthesis of the $N$-oxides.

UV-Vis spectra were recorded on scanning spectrophotometers (Shimadzu UV-1800, Shimadzu, Duisburg, Germany) at a constant temperature maintained by the use of thermostats attached to the instruments. All measurements were performed at $25.0 \pm 0.1{ }^{\circ} \mathrm{C}$. Standard $1.000 \mathrm{~cm}$ quartz cuvettes were used.

The $\mathrm{pH}$-metric and iodometric measurements were performed with a Metrohm 785 DMP Titrino (Metrohm Magyarország, Budapest, Hungary) automatic titrator equipped with 6.0262.100 and 6.0451.100 combined electrodes, respectively. The pH-electrode was calibrated by two buffers according to IUPAC recommendations [42]. The $\mathrm{pH}$ readings were converted to hydrogen ion concentration, as described by Irving et al. [43]. The acid-base equilibria of the $\mathrm{N}$-oxides were studied by various methods: standard $\mathrm{pH}$ potentiometric titration, combined $\mathrm{pH}$-potentiometric and $\mathrm{UV}$-vis spectrophotometric method or combined $\mathrm{pH}$-potentiometric and ${ }^{1} \mathrm{H}$ NMR technique.

ESI-TOF-MS measurements were made with a Bruker maXis II MicroTOF-Q type Qq-TOF-MS instrument (Bruker Daltonik, Bremen, Germany) in positive mode. The instrument was equipped with an electrospray ion source where the spray voltage was $4 \mathrm{kV} . \mathrm{N}_{2}$ was utilized as a drying gas and the drying temperature was $200{ }^{\circ} \mathrm{C}$. The spectra were accumulated and recorded using a digitalizer at a sampling rate of $2 \mathrm{GHz}$. The mass spectra were calibrated externally using the exact masses of the clusters generated from the electrosprayed solution of sodium trifluoroacetate (NaTFA). The spectra were analyzed with the DataAnalysis 4.4 software from Bruker.

1D ${ }^{1} \mathrm{H},{ }^{13} \mathrm{C}$ and 2D $\left({ }^{1} \mathrm{H}-{ }^{1} \mathrm{H}\right.$ COSY, and ${ }^{1} \mathrm{H}-{ }^{13} \mathrm{C}$ HSQC, HMBC) NMR spectra were recorded on a Bruker Avance I 400 spectrometer ((Bruker Daltonik, Bremen, Germany) equipped a $\mathrm{BB}$ inverse $z$ gradient probe at $298 \mathrm{~K}$ in $\mathrm{CDCl}_{3}$ solution with TMS, as an internal standard $(\delta=0 \mathrm{ppm})$. The COSY spectrum of phenO was obtained at $400 \mathrm{~Hz}$ in $\mathrm{D}_{2} \mathrm{O}$ solution with TMS, too. In the combined $\mathrm{pH}$-potentiometric and ${ }^{1} \mathrm{H}$ NMR method, the spectra were measured at $400 \mathrm{MHz}$. The solutions were prepared in $\mathrm{H}_{2} \mathrm{O}$, and DSS (4,4dimethyl-4-silapentane-1-sulfonic acid) in $\mathrm{D}_{2} \mathrm{O}$ was added to the sample in a capillary as an external standard for ${ }^{1} \mathrm{H}(0 \mathrm{ppm})$. The ${ }^{1} \mathrm{H}$ NMR spectra were recorded by using the standard watergate pulse sequence for the suppression of water proton signal. In each experiment, 32 scans were collected with $16 \mathrm{~K}$ data points using a sweep width of $5995 \mathrm{~Hz}$, a pulse angle of $90^{\circ}$, an acquisition time of $1.366 \mathrm{~s}$, and a relaxation delay of $1 \mathrm{~s}$. The HSQC spectra were collected by using gradient pulses in the $z$ direction with the standard Bruker pulse sequence.

The isomer $N$-oxides were separated by a $Y L 9100$ preparative HPLC system equipped with a YL 9120S UV/Vis detector and using Phenomenex Luna C18 column Nr 429545-1.

Non-linear least squares fittings of the different types of titration curves were performed with the software Scientist [44].

The ionic strength was kept constant by using appropriate amounts of sodium nitrate or sodium chloride in all experiments.

\subsection{The Preparation of 1,10-Phenanthroline-1-N-oxides}

A $\sim 15 \mathrm{mM}$ aqueous solution of the organic substrate was prepared. Small amounts of sulfuric acid were added to the solution to increase the solubility of the substrate and to provide slightly acidic conditions $(\mathrm{pH} \sim 2)$, which prevents di- $N$-oxidation. About 1.1-1.2 equivalent of solid PMS was added and the mixture was stirred at $60{ }^{\circ} \mathrm{C}$ for $2-38 \mathrm{~h}$. After complete conversion, the reaction mixture was neutralized by adding $\mathrm{NaOH}$ solution and the $\mathrm{pH}$ was set about $3-3.5 \mathrm{pH}$ unit above the $\mathrm{p} K_{\mathrm{a}}$ of the initial phen derivative to ensure that the produced $\mathrm{N}$-oxide completely deprotonates. After repeated extraction with $\mathrm{CHCl}_{3}(10 \mathrm{~mL} \times 3$ times), the combined organic extract was dried over anhydrous $\mathrm{Na}_{2} \mathrm{SO}_{4}$, filtered, and the solvent was removed under reduced pressure. In the case of nonsymmetrical initial phen derivatives, the oxidation results in the formation of structurally 
isomer mono- $N$-oxides. The isomers were separated by preparative HPLC. The separated fractions were concentrated to $1 / 10$ of the initial volume, extracted by $\mathrm{CHCl}_{3}$, the extract was dried over anhydrous $\mathrm{Na}_{2} \mathrm{SO}_{4}$, filtered, and the solvent was removed under reduced pressure.

1,10-phenanthroline-1-N-oxide (phenO). 1,10-Phenanthroline (phen) (150.26 mg, $0.758 \mathrm{mmol})$ was dissolved in water under acidic conditions $\left(30 \mathrm{~mL} \mathrm{H}_{2} \mathrm{O}, 200 \mu \mathrm{L} 2 \mathrm{M} \mathrm{H}_{2} \mathrm{SO}_{4}, \mathrm{pH}<2\right)$ and was reacted with potassium peroxomonosulfate (PMS) $(276.95 \mathrm{mg}, 0.778 \mathrm{mmol})$. The general procedure was followed and yellowish-brown solid was obtained $(128.91 \mathrm{mg}$, $0.65 \mathrm{mmol}$, yield 86.6\%). ${ }^{1} \mathrm{H} \mathrm{NMR}\left(400 \mathrm{MHz}, \mathrm{CDCl}_{3}, 25^{\circ} \mathrm{C}, \mathrm{TMS}\right) \delta(\mathrm{ppm}): 7.35$ (dd, $J=6.5$, $1.4 \mathrm{~Hz}, 1 \mathrm{H}, 8), 7.55(\mathrm{dd}, J=8.0,4.5 \mathrm{~Hz}, 1 \mathrm{H}, 3), 7.62(\mathrm{~m}, 1 \mathrm{H}, 7), 7.66(\mathrm{~m}, 1 \mathrm{H}, 5), 7.68(\mathrm{~m}, 1 \mathrm{H}$, 6), $8.11(\mathrm{dd}, J=8.0,1.4 \mathrm{~Hz} 1 \mathrm{H}, 4), 8.62(\mathrm{~d}, J=6.5 \mathrm{~Hz}, 1 \mathrm{H}, 9), 9.19(\mathrm{dd}, J=4.5,1.5 \mathrm{~Hz}, 1 \mathrm{H}, 2)$. ${ }^{13} \mathrm{C}$ NMR (100.6 MHz, CDCl $3,25^{\circ} \mathrm{C}$, TMS) $\delta$ (ppm): 121.8 (C8), 122.1 (C3), 123.8 (C7), 125.4 (C6), 127.9 (C4A), 128.0 (C5), 132.2 (C6A), 134.9(C4), 137.1 (C10A), 139.6 (C9), 141.4 (C10B), 148.8 (C2). ESI-MS calculated (calcd.) for $\mathrm{C}_{12} \mathrm{H}_{9} \mathrm{~N}_{2} \mathrm{O}^{+}[\mathrm{M}+\mathrm{H}]^{+}=197.0709$, found 197.0712.

2,9-dimethyl-1,10-phenanthroline-1-N-oxide (DMPO). 2,9-Dimethyl-1,10-phenanthroline (DMP) $(100.7 \mathrm{mg}, 0.484 \mathrm{mmol})$ was dissolved in water under acidic conditions $(30 \mathrm{~mL}$ $\left.\mathrm{H}_{2} \mathrm{O}, 100 \mu \mathrm{L} 2 \mathrm{M} \mathrm{H}_{2} \mathrm{SO}_{4}, \mathrm{pH}<2\right)$ and was reacted with PMS (177.0 mg, $\left.0.500 \mathrm{mmol}\right)$. The general procedure was followed, and dark purple solid was obtained $(91.0 \mathrm{mg}, 0.406 \mathrm{mmol}$, yield 83.91\%). ${ }^{1} \mathrm{H} \mathrm{NMR}\left(400 \mathrm{MHz} \mathrm{CDCl}_{3}, 25{ }^{\circ} \mathrm{C}\right.$, TMS) $\delta$ (ppm): 2.69 (s, 3H, 2), 2.86 (s, $3 \mathrm{H}, 9), 7.42(\mathrm{~d}, J=3.0 \mathrm{~Hz}, 1 \mathrm{H}, 7), 7.43(\mathrm{~d}, J=3.0 \mathrm{~Hz}, 1 \mathrm{H}, 4), 7.54(\mathrm{~d}, J=7.7 \mathrm{~Hz}, 1 \mathrm{H}, 8)$, $7.58(\mathrm{~d}, J=8.6 \mathrm{~Hz}, 1 \mathrm{H}, 6), 7.62(\mathrm{~d}, J=8.6 \mathrm{~Hz}, 1 \mathrm{H}, 5), 8.02(\mathrm{~d}, J=7.6 \mathrm{~Hz}, 1 \mathrm{H}, 3) .{ }^{13} \mathrm{C} \mathrm{NMR}$ (100.6 MHz, $\left.\mathrm{CDCl}_{3}, 25{ }^{\circ} \mathrm{C}, \mathrm{TMS}\right) \delta(\mathrm{ppm}): 18.5\left(-\mathrm{CH}_{3}(9)\right), 25.0\left(-\mathrm{CH}_{3}(2)\right), 122.4(\mathrm{C} 7), 122.6$ (C4), 123.0 (C8), 124.5 (C6), 126.0 (C10A), 126.9 (C5), 130.8 (C6A), 134.9 (C3), 137.0 (C4A), 141.2 (C10B), 149.2 (C9A), 157.7 (C2A). ESI-MS calcd. for $\mathrm{C}_{14} \mathrm{H}_{13} \mathrm{~N}_{2} \mathrm{O}^{+}[\mathrm{M}+\mathrm{H}]^{+}=225.1022$, found 225.1025, calcd. for $\mathrm{C}_{14} \mathrm{H}_{12} \mathrm{~N}_{2} \mathrm{ONa}^{+}[\mathrm{M}+\mathrm{Na}]^{+}=247.0842$, found 247.0840.

3,4,7,8-tetramethyl-1,10-phen- anthroline-1-N-oxide (TMPO). 3,4,7,8-Tetramethyl-1,10phenanthroline (TMP) $(150.12 \mathrm{mg}, 0.635 \mathrm{mmol})$ was dissolved in water under acidic conditions $\left(35 \mathrm{~mL} \mathrm{H}_{2} \mathrm{O}, 200 \mu \mathrm{L} 2 \mathrm{M} \mathrm{H}_{2} \mathrm{SO}_{4}, \mathrm{pH}<2\right)$ and was reacted with PMS (226.91 mg, $0.637 \mathrm{mmol})$. The general procedure was followed, and yellow solid was obtained $(141.26 \mathrm{mg}$, $0.559 \mathrm{mmol}$, yield 88.1\%). ${ }^{1} \mathrm{H}$ NMR (400 MHz, $\left.\mathrm{CDCl}_{3}, 25{ }^{\circ} \mathrm{C}, \mathrm{TMS}\right) \delta$ (ppm): 2.43 (s, 3H, 3), $2.53(\mathrm{~s}, 3 \mathrm{H}, 4), 2.61(\mathrm{~s}, 3 \mathrm{H}, 8), 2.67(\mathrm{~s}, 3 \mathrm{H}, 7), 7.94(\mathrm{~d}, J=9.6 \mathrm{~Hz}, 1 \mathrm{H}, 6), 8.06(\mathrm{~d}, J=9.6 \mathrm{~Hz}$, $1 \mathrm{H}, 5), 8.60(\mathrm{~s}, 1 \mathrm{H}, 9), 9.02(\mathrm{~s}, 1 \mathrm{H}, 2) .{ }^{13} \mathrm{C} \mathrm{NMR}\left(100.6 \mathrm{MHz}, \mathrm{CDCl}_{3}, 25{ }^{\circ} \mathrm{C}, \mathrm{TMS}\right) \delta(\mathrm{ppm})$ : 14.8 (C11), 15.0 (C12), 17.7(C13, C14), 122.1 (C6), 124.5 (C5), 127.3 (C3), 130.9 (C6A), 131.2 (C4,C7), 131.6 (C4A), 136.8 (C8), 141.0 (C10A), 141.1 (C9), 141.4 (C10B), 151.0 (C2). ESI-MS calcd. for $\mathrm{C}_{16} \mathrm{H}_{17} \mathrm{~N}_{2} \mathrm{O}^{+}[\mathrm{M}+\mathrm{H}]^{+}=253.1335$, found 253.1335 .

4-methyl-1,10-phenanthroline-1-N-oxide (4MPO) and 7-methyl-1,10-phenanthroline-1-Noxide (7MPO). 4-Methyl-1,10-phenanthroline (4MP) (150.12 mg, $0.776 \mathrm{mmol})$ was dissolved in water under acidic conditions $\left(30 \mathrm{~mL} \mathrm{H} \mathrm{H}_{2} \mathrm{O}, 100 \mu \mathrm{L} 2 \mathrm{M} \mathrm{H}_{2} \mathrm{SO}_{4}, \mathrm{pH}<2\right)$ and was reacted with PMS $(275.38 \mathrm{mg}, 0.773 \mathrm{mmol})$. The general procedure was followed and dark green solid was obtained $(134.65 \mathrm{mg}, 0.643 \mathrm{mmol}$, overall yield for the two isomers $82.8 \%$ ). The separation of the two isomers was achieved on Luna ${ }^{\circ}$ Prep C18(2) (100 $\AA$, $250 \mathrm{~mm} \times 21.2 \mathrm{~mm} ; 5 \mu \mathrm{m})$ column using isocratic elution with $16 \% \mathrm{Na}_{2} \mathrm{HPO}_{4}(5 \mathrm{mM}$ in water): $76 \% \mathrm{NaH}_{2} \mathrm{PO}_{4}(5 \mathrm{mM}$ in water): $8 \% \mathrm{ACN}$ solvent mixture as a mobile phase using $25 \mathrm{~mL} / \mathrm{min}$ flow-rate.

4-methyl-1,10-phenanthroline-1-N-oxide (4MPO): $\mathrm{HPLC} \mathrm{t}_{\mathrm{R}}=11.0 \mathrm{~min} .{ }^{1} \mathrm{H} \mathrm{NMR}(400 \mathrm{MHz}$, $\left.\mathrm{D}_{2} \mathrm{O}, 25^{\circ} \mathrm{C}, \mathrm{TMS}\right) \delta(\mathrm{ppm}): 3.01\left(\mathrm{~s}, 3 \mathrm{H},-\mathrm{CH}_{3}\right), 8.01(\mathrm{dd}, J=8.3,6.4 \mathrm{~Hz}, 1 \mathrm{H}, 8), 8.15(\mathrm{~d}, 1 \mathrm{H}$, $J=9.3 \mathrm{~Hz}, 5), 8.20(\mathrm{~d}, J=8.2 \mathrm{~Hz}, 1 \mathrm{H}, 3), 8.26(\mathrm{~d}, J=9.3 \mathrm{~Hz}, 1 \mathrm{H}, 6), 8.38(\mathrm{~d}, J=8.4 \mathrm{~Hz}, 1 \mathrm{H}$, 7), $8.87(\mathrm{dd}, J=6.3,0.7 \mathrm{~Hz}, 1 \mathrm{H}, 9), 9.00(\mathrm{~d}, J=5.8 \mathrm{~Hz}, 1 \mathrm{H}, 9) .{ }^{13} \mathrm{C} \mathrm{NMR}\left(100.6 \mathrm{MHz}, \mathrm{D}_{2} \mathrm{O}\right.$, $25^{\circ} \mathrm{C}$, TMS) $\delta$ (ppm): $19.1\left(-\mathrm{CH}_{3}\right), 123.9$ (C6), 125.7 (C8), 126.0 (C3), 127.9 (C6A), 128.3 (C5), 128.5 (C4), 131.2 (C4), 131.4 (C7), 132.1 (C10A), 139.6 (C9), 139.8 (C2), 157.1 (C10B). ESI-MS calcd. for $\mathrm{C}_{13} \mathrm{H}_{11} \mathrm{~N}_{2} \mathrm{O}^{+}[\mathrm{M}+\mathrm{H}]^{+}=211.0866$, found 211.0864, calcd. for $\mathrm{C}_{13} \mathrm{H}_{11} \mathrm{~N}_{2} \mathrm{ONa}^{+}$ $[\mathrm{M}+\mathrm{Na}]^{+}=233.0685$ found 233.0681 .

7-methyl-1,10-phenanthroline-1-N-oxide (7MPO): $\mathrm{HPLC} \mathrm{t}_{\mathrm{R}}=15.9 \mathrm{~min} .{ }^{1} \mathrm{H} \mathrm{NMR}(400 \mathrm{MHz}$, $\left.\mathrm{D}_{2} \mathrm{O}, 25^{\circ} \mathrm{C}, \mathrm{TMS}\right) \delta(\mathrm{ppm}): 2.83\left(\mathrm{~s}, 3 \mathrm{H},-\mathrm{CH}_{3}\right), 7.86(\mathrm{~d}, J=6.5 \mathrm{~Hz}, 1 \mathrm{H}, 8), 8.25(\mathrm{~d}, 1 \mathrm{H}$, 
$J=9.3 \mathrm{~Hz}, 5), 8.30(\mathrm{~d}, J=9.3 \mathrm{~Hz}, 1 \mathrm{H}, 6), 8.37(\mathrm{dd}, J=8.4,5.5 \mathrm{~Hz}, 1 \mathrm{H}, 3), 8.78(\mathrm{~d}, J=6.5 \mathrm{~Hz}$, $1 \mathrm{H}, 9), 9.16(\mathrm{dd}, J=8.5,1.3 \mathrm{~Hz}, 1 \mathrm{H}, 4), 9.22(\mathrm{dd}, J=5.6,1.4 \mathrm{~Hz}, 1 \mathrm{H}, 2) .{ }^{13} \mathrm{C} \mathrm{NMR}(100.6 \mathrm{MHz}$, $\mathrm{D}_{2} \mathrm{O}, 25^{\circ} \mathrm{C}$, TMS) $\delta$ (ppm): $17.7\left(-\mathrm{CH}_{3}\right), 125.1$ (C3), 125.3 (C6), 126.1 (C8), 127.1 (C5), 127.4 (C6A), 129.2 (C4A), 131.3 (C7), 132.7 (C10A), 138.4 (C9), 141.2 (C2), 142.2 (C10B), 144.4 (C4). ESI-MS calcd. for $\mathrm{C}_{13} \mathrm{H}_{11} \mathrm{~N}_{2} \mathrm{O}^{+}[\mathrm{M}+\mathrm{H}]^{+}=211.0866$, found 211.0865, calcd. for $\mathrm{C}_{13} \mathrm{H}_{11} \mathrm{~N}_{2} \mathrm{ONa}^{+}[\mathrm{M}+\mathrm{Na}]^{+}=233.0685$ found 233.0682 .

5-methyl-1,10-phenanthroline-1-N-oxide (5MPO) and 6-methyl-1,10-phenanthroline-N-oxide (6MPO).5-Methyl-1,10-phenanthroline (5MP) $(150.27 \mathrm{mg}, 0.777 \mathrm{mmol})$ was dissolved in water under acidic conditions ( $35 \mathrm{~mL} \mathrm{H}_{2} \mathrm{O}, 200 \mu \mathrm{L} 2 \mathrm{M} \mathrm{H}_{2} \mathrm{SO}_{4}, \mathrm{pH}<2$ ) and was reacted with PMS (279.60 mg, $0.785 \mathrm{mmol})$. The general procedure was followed, and pale brown solid was obtained $(129.36 \mathrm{mg}, 0.618 \mathrm{mmol}$, overall yield for the two isomers $79.5 \%)$. The preparative separation of the two isomers was achieved on Luna®Prep C18(2) (100 $\AA$, $250 \mathrm{~mm} \times 21.2 \mathrm{~mm} ; 5 \mu \mathrm{m})$ column using isocratic elution with $35 v / v \% \mathrm{Na}_{2} \mathrm{HPO}_{4}(5 \mathrm{mM}$ in water): $55 v / v \% \mathrm{NaH}_{2} \mathrm{PO}_{4}(5 \mathrm{mM}$ in water): $10 v / v \% \mathrm{ACN}$ solvent mixture as a mobile phase using $25 \mathrm{~mL} / \mathrm{min}$ flow-rate.

5-methyl-1,10-fenantroline-1-N-oxide (5MPO): HPLC: $\mathrm{t}_{\mathrm{R}}=21.8 \mathrm{~min} .{ }^{1} \mathrm{H}$ NMR $(400 \mathrm{MHz}$, $\left.\mathrm{D}_{2} \mathrm{O}, 25^{\circ} \mathrm{C}, \mathrm{TMS}\right) \delta(\mathrm{ppm}): 2.48\left(\mathrm{~s}, 3 \mathrm{H},-\mathrm{CH}_{3}\right), 7.55(\mathrm{~s}, 1 \mathrm{H}, 6), 7.83(\mathrm{dd}, J=8.6,6.3 \mathrm{~Hz}, 1 \mathrm{H}, 8)$, $8.08(\mathrm{dd}, J=8.3,5.2 \mathrm{~Hz}, 1 \mathrm{H}, 3), 8.18(\mathrm{dd}, J=8.6,0.6 \mathrm{~Hz}, 1 \mathrm{H}, 7), 8.61(\mathrm{dd}, J=8.3,1.3 \mathrm{~Hz}, 1 \mathrm{H}$, 4), $8.68(\mathrm{dd}, J=6.3,0.6 \mathrm{~Hz}, 1 \mathrm{H}, 9), 8.95(\mathrm{dd}, \mathrm{J}=5.3,1.4 \mathrm{~Hz}, 1 \mathrm{H}, 2) .{ }^{13} \mathrm{C} \mathrm{NMR}(100.6 \mathrm{MHz}$, $\mathrm{D}_{2} \mathrm{O}, 25^{\circ} \mathrm{C}$, TMS) $\delta$ (ppm): $17.7\left(-\mathrm{CH}_{3}\right), 124.2(\mathrm{C} 8), 124.4(\mathrm{C} 3), 125.8$ (C6), $126.8(\mathrm{C} 7), 128.2$ (C10B), 128.5 (C6A), 131.6 (C5), 131.7 (C4A), 135.4 (C10A), 138.5 (C2), 141.2 (C9), 141.5 (C4). ESI-MS calcd. for $\mathrm{C}_{13} \mathrm{H}_{11} \mathrm{~N}_{2} \mathrm{O}^{+}[\mathrm{M}+\mathrm{H}]^{+}=211.0866$, found 211.0868 .

6-methyl-1,10-fenantroline-1-N-oxide (6MPO): HPLC: $\mathrm{t}_{\mathrm{R}}=24.5 \mathrm{~min} .{ }^{1} \mathrm{H} \mathrm{NMR}(400 \mathrm{MHz}$, $\left.\mathrm{D}_{2} \mathrm{O}, 25^{\circ} \mathrm{C}, \mathrm{TMS}\right) \delta(\mathrm{ppm}): 2.32\left(\mathrm{~s}, 3 \mathrm{H},-\mathrm{CH}_{3}\right), 7.25(\mathrm{~s}, 1 \mathrm{H}, 5), 7.64(\mathrm{dd}, J=8.1,6.3 \mathrm{~Hz}, 1 \mathrm{H}$, 8), $7.77(\mathrm{~d}, J=8.3 \mathrm{~Hz}, 1 \mathrm{H}, 7), 7.95(\mathrm{dd}, J=8.4,5.0 \mathrm{~Hz}, 1 \mathrm{H}, 3), 8.49(\mathrm{~d}, J=6.2 \mathrm{~Hz}, 1 \mathrm{H}, 9), 8.57$ $(\mathrm{d}, J=8.2 \mathrm{~Hz}, 1 \mathrm{H}, 4), 8.87(\mathrm{dd}, J=5.1,0.9 \mathrm{~Hz}, 1 \mathrm{H}, 2) .{ }^{13} \mathrm{C} \mathrm{NMR}\left(100.6 \mathrm{MHz}, \mathrm{D}_{2} \mathrm{O}, 25^{\circ} \mathrm{C}\right.$, TMS) $\delta$ (ppm): $16.7\left(-\mathrm{CH}_{3}\right), 123.7$ (C3), 124.1 (C8), 125.5 (C5), 127.6 (C6A), 127.9 (C6), 129.0 (C7), 131.0 (C10A), 133.3 (C4A), 134.7 (C10B), 137.6 (C4), 138.0 (C9), 142.2 (C2). ESI-MS calcd. for $\mathrm{C}_{13} \mathrm{H}_{11} \mathrm{~N}_{2} \mathrm{O}^{+}[\mathrm{M}+\mathrm{H}]^{+}=211.0866$, found 211.0866.

5-chloro-1,10-phenanthroline-1-N-oxide (5CPO) and 6-chloro-1,10-phenanthroline-1-N-oxide (6CPO). 5-Chloro-1,10-phenanthroline (5CP) $(100.1 \mathrm{mg}, 0.430 \mathrm{mmol})$ was dissolved in water under acidic conditions $\left(30 \mathrm{~mL} \mathrm{H}_{2} \mathrm{O}, 100 \mu \mathrm{L} 3 \mathrm{M} \mathrm{H}_{2} \mathrm{SO}_{4}, \mathrm{pH}<2\right.$ ) and was reacted with PMS (173 mg, $0.489 \mathrm{mmol})$. The general procedure was followed, and pale brown solid was obtained $(86.5 \mathrm{mg}, 0.375 \mathrm{mmol}$, overall yield for the two isomers $87.2 \%)$. The preparative separation of the two isomers was achieved on Luna®Prep C18(2) column $(100 \AA, 250 \mathrm{~mm} \times 21.2 \mathrm{~mm})$ using acetonitrile $-0.005 \mathrm{M}$ citrate buffer $(\mathrm{pH}=6.27)$ solvent mixture at $19 / 81 \mathrm{v} / \mathrm{v}$ ratio as a mobile phase with the flow-rate of $25 \mathrm{~mL} / \mathrm{min}$.

5-chloro-1,10-fenantroline-1-N-oxide (5CPO): HPLC: $\mathrm{t}_{\mathrm{R}}=11.4 \mathrm{~min} .{ }^{1} \mathrm{H} \mathrm{NMR}(400 \mathrm{MHz}$, $\mathrm{CDCl}_{3}, 25{ }^{\circ} \mathrm{C}$, TMS) $\delta(\mathrm{ppm}): 7.42(\mathrm{t}, J=8.4,6.9 \mathrm{~Hz}, 1 \mathrm{H}, 8), 7.60(\mathrm{~d}, J=8.4 \mathrm{~Hz}, 1 \mathrm{H}, 7)$, $7.72(\mathrm{dd}, J=8.4,4.4 \mathrm{~Hz}, 1 \mathrm{H}, 3), 7.82(\mathrm{~s}, 1 \mathrm{H}, 6), 8.66(\mathrm{~s}, 2 \mathrm{H}, 4,9), 9.29(\mathrm{~d}, J=3.1 \mathrm{~Hz}, 1 \mathrm{H}$, 2). ${ }^{13} \mathrm{C}$ NMR (100.6 MHz, $\mathrm{CDCl}_{3}, 25^{\circ} \mathrm{C}$, TMS) $\delta$ (ppm): 122.5 (C8), $122.6(\mathrm{C} 3, \mathrm{C} 7), 124.7$ (C6), 125.7 (C6A), 131.3 (C5), 131.6 (C4A), 132.0 (C4), 136.3 (C10A), 140.1 (C9), 142.0 (C10B), 149.3 (C2). ESI-MS calcd. for $\mathrm{C}_{12} \mathrm{H}_{8} \mathrm{~N}_{2} \mathrm{OCl}^{+}[\mathrm{M}+\mathrm{H}]^{+}=231.0320$, found 231.0325, calcd. for $\mathrm{C}_{12} \mathrm{H}_{7} \mathrm{~N}_{2} \mathrm{OClNa}{ }^{+}[\mathrm{M}+\mathrm{Na}]^{+}=253.0139$, found 253.0148.

6-chloro-1,10-fenantroline-1-N-oxide (6CPO): HPLC: $\mathrm{t}_{\mathrm{R}}=10.3 \mathrm{~min} .{ }^{1} \mathrm{H} \mathrm{NMR}(400 \mathrm{MHz}$, $\left.\mathrm{CDCl}_{3}\right) \delta(\mathrm{ppm}): 7.51(\mathrm{dd}, J=8.3,6.4 \mathrm{~Hz}, 1 \mathrm{H}, 8), 7.62(\mathrm{dd}, J=8.0,4.4 \mathrm{~Hz}, 1 \mathrm{H}, 3), 7.89(\mathrm{~s}, 1 \mathrm{H}$, 5), $8.10(\mathrm{dd}, J=8.2,1.4 \mathrm{~Hz}, 1 \mathrm{H}, 4), 8.17(\mathrm{~d}, J=8.4 \mathrm{~Hz}, 7), 8.72(\mathrm{~d}, J=6.3 \mathrm{~Hz}, 1 \mathrm{H}, 9), 9.24(\mathrm{dd}$, $J=4.5,1.6 \mathrm{~Hz}, 1 \mathrm{H}, 2) .{ }^{13} \mathrm{C}$ NMR $\left(100.6 \mathrm{MHz}, \mathrm{CDCl}_{3}, 25^{\circ} \mathrm{C}\right.$, TMS) $\delta$ (ppm): $120.4(\mathrm{C} 7), 122.1$ (C8), 122.8 (C3), 127.1 (C4A), 127.4 (C5), 128.6 (C6A), 130.3 (C6), 134.2 (C4), 138.1 (C10A), 140.4 (C9), 140.6 (C10B), 149.1 (C2). ESI-MS calcd. for $\mathrm{C}_{12} \mathrm{H}_{8} \mathrm{~N}_{2} \mathrm{OCl}^{+}[\mathrm{M}+\mathrm{H}]^{+}=231.0320$, found 231.0327, calcd. for $\mathrm{C}_{12} \mathrm{H}_{7} \mathrm{~N}_{2} \mathrm{OClNa}^{+}[\mathrm{M}+\mathrm{Na}]^{+}=253.0139$, found 231.0150.

5-nitro-1,10-phenanthroline-1-N-oxide (5NPO) and 6-nitro-1,10-phenanthroline-1-N-oxide (6NPO). 5-Nitro-1,10-phenanthroline ( $99.9 \mathrm{mg}, 0.411 \mathrm{mmol})$ was dissolved in water under acidic conditions $\left(30 \mathrm{~mL} \mathrm{H}_{2} \mathrm{O}, 100 \mu \mathrm{L} 3 \mathrm{M} \mathrm{H}_{2} \mathrm{SO}_{4}, \mathrm{pH}<2\right)$ and was reacted with PMS 
(164 mg, $0.463 \mathrm{mmol})$. The general procedure was followed, and orange solid was obtained (91.2 $\mathrm{mg}, 0.378 \mathrm{mmol}$, overall yield for the two isomers 92.1\%). Eluent used for the separation of the isomers was as follows: $0.005 \mathrm{M}$ acetic acid (the $\mathrm{pH}$ was adjusted to 5.12 by adding an appropriate amount of $\mathrm{NaOH}$ ) and $\mathrm{ACN}$ solvent mixture at 90/10 v/v ratio. The preparative separation of the two isomers was achieved on Luna®Prep C18(2) column $(100 \AA, 250 \mathrm{~mm} \times 21.2 \mathrm{~mm})$ using $25 \mathrm{~mL} / \mathrm{min}$ flow rate.

5-nitro-1,10-fenantroline-1-N-oxide (5NPO): HPLC: $\mathrm{t}_{\mathrm{R}}=14.9 \mathrm{~min} .{ }^{1} \mathrm{H} \mathrm{NMR}(400 \mathrm{MHz}$, $\left.\mathrm{CDCl}_{3}, 25^{\circ} \mathrm{C}, \mathrm{TMS}\right) \delta(\mathrm{ppm}): 7.54(\mathrm{dd}, J=8.0,6.5 \mathrm{~Hz}, 1 \mathrm{H}, 8), 7.77(\mathrm{dd}, J=8.6,4.4 \mathrm{~Hz}, 1 \mathrm{H}$, 3), $7.84(\mathrm{~d}, J=8 \mathrm{~Hz}, 1 \mathrm{H}, 7), 8.45(\mathrm{~s}, 1 \mathrm{H}, 6), 8.78(\mathrm{dd}, J=6.4,0.5 \mathrm{~Hz}, 1 \mathrm{H}, 9), 8.82(\mathrm{dd}, J=8.6$, $1.6 \mathrm{~Hz}, 1 \mathrm{H}, 4), 9.33(\mathrm{dd}, J=4.4,1.6 \mathrm{~Hz}, 1 \mathrm{H}, 2) .{ }^{13} \mathrm{C} \mathrm{NMR}\left(100.6 \mathrm{MHz}, \mathrm{CDCl}_{3}, 25{ }^{\circ} \mathrm{C}, \mathrm{TMS}\right) \delta$ (ppm): 119.5 (C6A), 123.2 (C8), 123.3 (C3), 123.5 (C6), 124.6 (C7), 129.3 (C4A), 130.7 (C4), 138.3 (C10B), 142.0 (C10A), 142.7 (C9), 144.9 (C5), 149.8 (C2). ESI-MS calcd. for $\mathrm{C}_{12} \mathrm{H}_{8} \mathrm{~N}_{3} \mathrm{O}_{3}{ }^{+}$ $[\mathrm{M}+\mathrm{H}]^{+}=242.0561$, found 242.0560, calcd. for $\mathrm{C}_{12} \mathrm{H}_{7} \mathrm{~N}_{3} \mathrm{O}_{3} \mathrm{Na}^{+}[\mathrm{M}+\mathrm{Na}]^{+}=264.0380$, found 264.0380 .

6-nitro-1,10-fenantroline-1-N-oxide (6NPO): HPLC: $\mathrm{t}_{\mathrm{R}}=13.4 \mathrm{~min} .{ }^{1} \mathrm{H} \mathrm{NMR}(400 \mathrm{MHz}$, $\left.\mathrm{D}_{2} \mathrm{O}(+\mathrm{NaOD}), 25^{\circ} \mathrm{C}, \mathrm{TMS}\right) \delta(\mathrm{ppm}): 6.01(\mathrm{~s}, 1 \mathrm{H}, 5), 7.53(\mathrm{t}, J=7.3 \mathrm{~Hz}, 1 \mathrm{H}, 8), 7.57(\mathrm{dd}, J=8.2$, $4.7 \mathrm{~Hz}, 1 \mathrm{H}, 3), 7.74(\mathrm{~d}, J=7.7 \mathrm{~Hz}, 1 \mathrm{H}, 7), 8.31(\mathrm{~d}, J=6.5 \mathrm{~Hz}, 1 \mathrm{H}, 9), 8.58(\mathrm{dd}, J=4.8,1.0 \mathrm{~Hz}$, $1 \mathrm{H}, 4), 8.81(\mathrm{dd}, J=8.5,1 \mathrm{~Hz}, 1 \mathrm{H}, 2) .{ }^{13} \mathrm{C} \mathrm{NMR}\left(100.6 \mathrm{MHz}, \mathrm{D}_{2} \mathrm{O}(+\mathrm{NaOD}), 25^{\circ} \mathrm{C}, \mathrm{TMS}\right) \delta$ (ppm): 66.0 (C5), 121.2 (C6A), 123.6 (C3), 124.9 (C8), 127.6 (C4A), 129.4 (C7), 136.6 (C2), 138.9 (C10B), 139.0 (C9), 141.8 (C10A), 142.3 (C6), 145.7 (C4). ESI-MS calcd. for $\mathrm{C}_{12} \mathrm{H}_{8} \mathrm{~N}_{3} \mathrm{O}_{3}{ }^{+}$ $[\mathrm{M}+\mathrm{H}]^{+}=242.0565$, found 242.0560, calcd. for $\mathrm{C}_{12} \mathrm{H}_{7} \mathrm{~N}_{3} \mathrm{O}_{3} \mathrm{Na}^{+}[\mathrm{M}+\mathrm{Na}]^{+}=264.0389$, found 264.0380 .

\subsection{X-ray Structures of 1,10-Phenatroline-1-N-oxide Derivatives}

Suitable single crystals of 1,10-phenatroline- $1-N$-oxide derivatives were mounted on the Mitegen loops with oil. Data sets were collected at $100 \mathrm{~K}$ or room temperature on a Bruker D8 Venture (SC-XRD) diffractometer (Bruker Daltonik, Bremen, Germany) system using INCOATEC I $\mu$ S 3.0 dual $(\mathrm{Mo}, \mathrm{Cu}$ ) sealed tube microsources (Mo-K $\alpha$ irradiation $(\lambda=0.71073 \AA$ ) was applied for all measurements). and Photon II Charge-integrating Pixel Array detector. Bruker APEX3 software was applied to collect and made the absorption correction using the MULTI-SCAN method and integration of the data sets [45]. The structures were solved by the direct method using SHELXT [46] and refined on $F^{2}$ data using full matrix least-squares by SHELXL [47], were managed with OLEX ${ }^{2}$ [48] and WinGX software suites [49]. All non-hydrogen atoms were refined anisotropically. All hydrogens were included in the model at geometrically calculated positions and refined using the riding model. $\mathrm{OH}$ (water) hydrogens were located on the difference electron density map.

The optimized structures of the compounds were analyzed using PLATON [50]; publication materials were prepared with the Mercury CSD-4.3.0 [51] and OLEX² software.

The crystallographic data for all compounds were deposited in the Cambridge Crystallographic Data Centre (CCDC) with the No. CCDC 2075043, 2075044, 2075045, 2075046.

\subsection{DFT and TD-DFT Calculations}

The ground state geometry optimization of the protonated $N$-oxides was computed through Gaussian 09 Rev. C.01 [52] software at DFT level of theory using the hybrid B3P86 functional and the triple- $\zeta$ def2-TZVP basis set [53]. In all cases, the polarizable continuum model (PCM) for water was used to take into account the effect of the solvent [54]. Harmonic frequency calculations were computed at the same level of theory for the ground state compounds which represented true minima on the potential energy surface (PES).

The electronic transitions were calculated at TD-DFT level of theory using PCM for water. Ten functionals were tested which are as follows: functionals based on the generalized gradient approximations (GGA) including CAM-B3LYP [55], $\omega-B 97 x-D$ [56], HSE06 [57], BH\&HLYP [52]; the meta GGA functionals TPSSh [58], M06 [59], M06-2X [59], tHCTH [60] and the pure BLYP [61] and TPSS functionals [58]. All of them were combined 
with the def2-TZVP basis set. The molecular orbitals involved in the transitions were simulated through Mulliken population analysis at TPSSh/def2-TZVP level of theory. The representation of the UV-Vis spectra was generated using the GaussSum software [62].

\section{Conclusions}

The oxidation of substituted phen derivatives by PMS yields only the corresponding mono- $\mathrm{N}$-oxides under acidic conditions because the intramolecular hydrogen bond involving the un-oxidized $\mathrm{N}$ and the $\mathrm{N}-\mathrm{O}$ moiety inhibits further oxidation of the primary product. This resistance towards di-N-oxidation was utilized for the synthesis of a series of phenO-s. The reaction conditions are mild, the procedure is simple and results in the mono- $\mathrm{N}$-oxides with good to excellent yields. The very nature of these compounds is still to be explored. They may prove valuable as specific ligands in coordination chemistry, as new precursors of building blocks in material science, materials for altering surfaces in electrochemical processes, etc. Our ongoing studies have already been directed toward evaluating these aspects of the chemistry of mono- $\mathrm{N}$-oxides of 1-10 phenanthroline.

Supplementary Materials: The following are available online: HPLC chromatogram recorded in the phen/PMS system. Copies of the NMR and mass spectra of the compounds (Figures S2-S58), pH dependent NMR spectra of the asymmetric $N$-oxides (Figures S59-S61), molecular structures and selected partial packing diagrams of the mono-N-oxides (Figures S62-S72), crystallographic data of the $\mathrm{N}$-oxides (Table S1), selected bond lengths and hydrogen bonds of the $\mathrm{N}$-oxides (Tables S2-S10), experimental and calculated UV-Vis spectra (Figures S73-S80), Computed total energies and molecular geometry in Cartesian coordinates (Tables S11-S21), calculated and experimental transitions of the $N$-oxides (Table S22).

Author Contributions: Conceptualization, all authors (F.N., M.S., N.L., A.U., I.F.) methodology, F.N., M.S., N.L. and A.U.; discussion of experimental results, all authors; writing-original draft preparation, M.S., N.L., A.U., I.F.; writing-review and editing, M.S., N.L., A.U., I.F.; supervision, and funding acquisition, I.F. All authors have read and agreed to the published version of the manuscript.

Funding: Support by the National Research, Development and Innovation Found (K-124983, PD128326, and FK-128333) is gratefully acknowledged. This research was funded by the EU and co-financed by the European Regional Development Fund (under the project GINOP-2.3.3-15-201600004), and by the Thematic Excellence Programme (TKP2020-NKA-04) of the Ministry for Innovation and Technology of Hungary. N. L. is indebted to the New National Excellence Program of the Ministry for Innovation and Technology (ÚNKP-20-4-II).

Institutional Review Board Statement: Not applicable.

Informed Consent Statement: Not applicable.

Acknowledgments: Gáspár Attila and László Krusper are gratefully acknowledged for their assistance in the ESI-MS measurements and HPLC analysis, respectively.

Conflicts of Interest: The authors declare no conflict of interest.
Abbreviations
phenO 1:10-phenanthroline-1- $N$-oxide
DMPO 2,9-dimethyl-1,10-phenanthroline-1-N-oxide
TMPO 3,4,7,8-tetramethyl-1,10-phenanthroline-1-N-oxide
$5 \mathrm{MPO}$ 5-methyl-1,10-phenanthroline-1- $\mathrm{N}$-oxide
6MPO 6-methyl-1,10-phenanthroline-1-N-oxide
$5 \mathrm{NPO}$ 5-nitro-1,10-phenanthroline-1-N-oxide
$6 \mathrm{NPO}$ 6-nitro-1,10-phenanthroline-1- $\mathrm{N}$-oxide
$5 \mathrm{CPO}$ 5-chloro-1,10-phenanthroline-1-N-oxide
6CPO 6-chloro-1,10-phenanthroline-1-N-oxide
4MPO 4-methyl-1,10-phenanthroline-1-N-oxide
7MPO 7-methyl-1,10-phenanthroline-1- $N$-oxide 


\section{References}

1. Bentley, K.W.; Wolf, C. Comprehensive chirality censing: Development of stereodynamic probes with a dual (chir)optical response. J. Org. Chem. 2014, 79, 6517-6531. [CrossRef]

2. Yang, W.; Zhang, R.; Yi, F.; Cai, M. A heterogeneous gold(I)-catalyzed $[2+2+1]$ annulation of terminal alkynes, nitriles, and oxygen atoms leading to 2,5-disubstituted oxazoles. J. Org. Chem. 2017, 82, 5204-5211. [CrossRef]

3. Schütznerová, E.; Krchňák, V. N-Oxide as an intramolecular oxidant in the Baeyer-Villiger oxidation: Synthesis of 2-alkyl-2Hindazol-3-yl benzoates and 2-alkyl-1,2-dihydro-3H-indazol-3-ones. J. Org. Chem. 2016, 81, 3585-3596. [CrossRef]

4. Su, Y.; Zhou, X.; He, C.; Zhang, W.; Ling, X.; Xiao, X. In situ generated hypoIodite activator for the C2 sulfonylation of heteroaromatic N-oxides. J. Org. Chem. 2016, 81, 4981-4987. [CrossRef]

5. Wang, Y.; Yin, H.; Tang, X.; Wu, Y.; Meng, Q.; Gao, Z. A series of cinchona-derived N-oxide phase-transfer catalysts: Application to the photo-organocatalytic enantioselective $\alpha$-hydroxylation of $\beta$-dicarbonyl compounds. J. Org. Chem. 2016, 81, 7042-7050 [CrossRef]

6. Odani, R.; Hirano, K.; Satoh, T.; Miura, M. Copper-mediated formally dehydrative biaryl coupling of azine N-oxides and oxazoles. J. Org. Chem. 2015, 80, 2384-2391. [CrossRef]

7. Rouchet, J.-B.E.Y.; Schneider, C.; Fruit, C.; Hoarau, C. Regioselective decarboxylative cross-coupling of carboxy isoquinoline N-oxides. J. Org. Chem. 2015, 80, 5919-5927. [CrossRef]

8. Han, Y.-P.; Li, X.-S.; Zhu, X.-Y.; Li, M.; Zhou, L.; Song, X.-R.; Liang, Y.-M. Lewis acid catalyzed dehydrogenative coupling of tertiary propargylic alcohols with quinoline N-oxides. J. Org. Chem. 2017, 82, 1697-1704. [CrossRef] [PubMed]

9. Li, J.; Bauer, A.; Di Mauro, G.; Maulide, N. $\alpha$-Arylation of carbonyl compounds through oxidative C-C bond activation. Angew. Chem. Int. Ed. 2019, 58, 9816-9819. [CrossRef]

10. Vamos, M.; Cosford, N.D.P. 2-Aminopyridines via reaction of pyridine N-oxides and activated isocyanides. J. Org. Chem. 2014, 79, 2274-2280. [CrossRef]

11. Aithagani, S.K.; Kumar, M.; Yadav, M.; Vishwakarma, R.A.; Singh, P.P. Metal-free, phosphonium salt-mediated sulfoximination of azine N-oxides: Approach for the synthesis of N-azine sulfoximines. J. Org. Chem. 2016, 81, 5886-5894. [CrossRef] [PubMed]

12. Loska, R. Recent Advances in Cycloaddition Reactions of Heterocyclic N-Oxides. In Heterocyclic N-Oxides; Larionov, O.V., Ed.; Springer International Publishing: Cham, Switzerland, 2017; Volume 53, pp. 85-110. [CrossRef]

13. Poole, J.S. Recent Advances in the Photochemistry of Heterocyclic N-Oxides and Their Derivatives. In Heterocyclic N-Oxides; Larionov, O.V., Ed.; Springer International Publishing: Cham, Switzerland, 2017; Volume 53, pp. 111-151. [CrossRef]

14. Zhou, W.; Miura, T.; Murakami, M. Photocatalyzed ortho-alkylation of pyridine N-oxides through alkene cleavage. Angew. Chem. Int. Ed. 2018, 57, 5139-5142. [CrossRef] [PubMed]

15. Koukal, P.; Ulč, J.; Nečas, D.; Kotora, M. Pyridine N-oxides and derivatives thereof in organocatalysis. In Heterocyclic N-Oxides; Larionov, O.V., Ed.; Springer International Publishing: Cham, Switzerland, 2017; Volume 53, pp. 29-58. [CrossRef]

16. Staniland, S.; Adams, R.W.; McDouall, J.J.W.; Maffucci, I.; Contini, A.; Grainger, D.M.; Turner, N.J.; Clayden, J. Biocatalytic dynamic kinetic resolution for the synthesis of atropisomeric biaryl N-oxide Lewis base catalysts. Angew. Chem. Int. Ed. 2016, 55, 10755-10759. [CrossRef] [PubMed]

17. Murray, J.I.; Flodén, N.J.; Bauer, A.; Fessner, N.D.; Dunklemann, D.L.; Bob-Egbe, O.; Rzepa, H.S.; Bürgi, T.; Richardson, J.; Spivey, A.C. Kinetic resolution of 2-substituted indolines by N-sulfonylation using an atropisomeric 4-DMAP-N-oxide organocatalyst. Angew. Chem. Int. Ed. 2017, 56, 5760-5764. [CrossRef]

18. Speca, A.N.; Karayannis, N.M.; Pytlewski, L.L. Chromium(III) and iron(III) perchlorate with the mono-N-oxides of 2,2'-bipyridine and 1,10-phenanthroline. Inorg. Chim. Acta 1974, 9, 87-93. [CrossRef]

19. De Andrade, A.C.M.; de Brito, M.A.; Coelho, A.L.; de Sá, G.F. 1,10-phenanthroline N-oxide complex with europium(III). Inorg. Chim. Acta 1976, 19, L19-L20. [CrossRef]

20. Karayannis, N.M.; Speca, A.N.; Chasan, D.E.; Pytlewski, L.L. Coordination complexes of the N-oxides of aromatic diimines and diazines. Coord. Chem. Rev. 1976, 20, 37-80. [CrossRef]

21. Speca, A.N.; Pytlewski, L.L.; Karayannis, N.M. Transition metal chloride chelates with 1,10-phenanthroline N-oxide. Z. Anorg. Allg. Chem. 1976, 422, 182-192. [CrossRef]

22. Speca, A.N.; Pytlewski, L.L.; Owens, C.; Karayannis, N.M. 2,2'-bipyridine- and 1,10-phenanthroline-N-oxide chelates with chromium(III) and iron(III) nitrates[1]. J. Inorg. Nucl. Chem. 1976, 38, 1119-1124. [CrossRef]

23. Agarwal, R.K.; Jain, P.C.; Kapur, V.; Sharma, S.; Srivastava, A.K. Thorium(IV) and zirconium complexes of oxygen donor ligands. 12. Thorium complexes of mono-N-oxides of 2,2' bipyridine and 1,10 phenanthroline. Transition Met. Chem. 1980, 5, 237-239. [CrossRef]

24. Owens, C.; Filo, A.K.; Woods, J.M.; Pytlewski, L.L.; Speca, A.N.; Karayannis, N.M. Labile 1,10-phenanthroline N-oxide complexes with tin(II) and (IV) halides. Inorg. Chim. Acta Lett. 1980, 45, L27-L30. [CrossRef]

25. Chassapis, C.; Pneumatikakis, G. 1,10-phenanthroline-N-oxide chelates with rare-earth nitrates. Inorg. Chim. Acta Art. 1982, 59, 49-52. [CrossRef]

26. Prakash, D.; Singh, S.P. Alkali-metal complexes-adducts of alkali-metal salts of some organic-acids with I,10-phenanthrolinemono-N-oxide. J. Indian Chem. Soc. 1987, 64, 182-183.

27. Goel, N. A uranium (VI) complex: Synthesis, structural and thermal kinetic analysis. J. Mol. Struct. 2016, 1117, 147-152. [CrossRef] 
28. Zhang, L.J.; Zhu, H.W.; Guo, Y.; Zhou, Y.S.; Yue, Q.; Shi, Z.H. Synthesis, structures and photoluminescence of a series of 3D lanthanide-organic coordination polymers constructed from versatile $2,2^{\prime}$-bipyridine-3,3'-dicarboxylic acid $1,1^{\prime}$-dioxide and oxalic acid. Crystengcomm 2015, 17, 4150-4160. [CrossRef]

29. Moustafa, M.E.; Boyle, P.D.; Puddephatt, R.J. Carbon-hydrogen versus nitrogen-oxygen bond activation in reactions of N-oxide derivatives of 2,2'-bipyridine and 1,10-phenanthroline with a dimethylplatinum(II) complex. Organometallics 2014, 33, 5402-5413. [CrossRef]

30. Linsker, F.; Evans, R.L. Phenanthroline di-N-oxides. J. Am. Chem. Soc. 1946, 68, 403-403. [CrossRef]

31. Maerker, G.; Case, F.H. The synthesis of some 4,4'-disubstituted 2,2'-bipyridines. J. Am. Chem. Soc. 1958, 80, 2745-2748. [CrossRef]

32. Corey, E.J.; Borror, A.L.; Foglia, T. Transformations in the 1,10-Phenanthroline Series. J. Org. Chem. 1965, 30, 288-290. [CrossRef]

33. Wenkert, D.; Woodward, R.B. Studies of 2,2'-bipyridyl N,N'-dioxides. J. Org. Chem. 1983, 48, 283-289. [CrossRef]

34. Balicki, R.; Golinski, J. A simple and efficient method for the preparation of N-heteroaromatic N-oxides. Synth. Commun. 2000, 30, 1529-1534. [CrossRef]

35. Rozen, S.; Dayan, S. At last, 1,10-phenanthroline-N,N'-dioxide, a new Type of helicene, has been synthesized using HOF. $\mathrm{CH} 3 \mathrm{CN}$. Angew. Chem. Int. Ed. 1999, 38, 3471-3473. [CrossRef]

36. Bellér, G.; Szabó, M.; Lente, G.; Fábián, I. Formation of 1,10-phenanthroline-N,N'-dioxide under mild conditions: The kinetics and mechanism of the oxidation of 1,10-phenanthroline by peroxomonosulfate ion (Oxone). J. Org. Chem. 2016, 81, 5345-5353. [CrossRef]

37. Najóczki, F.; Bellér, G.; Szabó, M.; Fábián, I. Substituent effect on the N-oxidation of 1,10-phenanthroline derivatives by peroxomonosulfate ion. New J. Chem. 2017, 41, 9947-9953. [CrossRef]

38. Newkome, G.R.; Theriot, K.J.; Gupta, V.K.; Fronczek, F.R.; Baker, G.R. Chemistry of heterocyclic compounds. 124. Mono-.alpha.functionalization of 2,9-dimethyl-1,10-phenanthroline. J. Org. Chem. 1989, 54, 1766-1769. [CrossRef]

39. Szabó, K.; Nagypál, I.; Fábián, I. Unexpected dependence of the protonation constant of 2,2'-bipyridyl on ionic strength. Talanta 1983, 30, 801-804. [CrossRef]

40. Simon, A.; Ballai, C.; Lente, G.; Fábián, I. Structure-reactivity relationships and substituent effect additivity in the aqueous oxidation of chlorophenols by cerium(iv). New J. Chem. 2011, 35, 235-241. [CrossRef]

41. Kutyła, S.E.; Stępień, D.K.; Jarzembska, K.N.; Kamiński, R.; Dobrzycki, Ł.; Ciesielski, A.; Boese, R.; Młochowski, J.; Cyrański, M.K. Structural and stability studies of a series of para-phenylenediboronic and para-hydroxyphenylboronic acid cocrystals with selected aromatic N-Oxides. Cryst. Growth Des. 2016, 16, 7037-7050. [CrossRef]

42. Covington, A.K. Definition of $\mathrm{pH}$ Scales, Standard reference values, measurement of $\mathrm{pH}$ and related terminology. Pure Appl. Chem. 1983, 55, 1467-1476. [CrossRef]

43. Irving, H.M.; Miles, M.G.; Pettit, L.D. A study of some problems in determining the stoicheiometric proton dissociation constants of complexes by potentiometric titrations using a glass electrode. Anal. Chim. Acta 1967, 38, 475-488. [CrossRef]

44. Scientist, Version 2.0; Micromath Scientific Software: Salt Lake City, UT, USA, 1995.

45. Bruker. APEX3 (version: 6.2.6), SAINT (version: 8.38A), SADABS (version: 2016/2), Bruker AXS Inc.: Madison, WI, USA, 2017.

46. Sheldrick, G. SHELXT - Integrated space-group and crystal-structure determination. Acta Crystallogr. A 2015, 71, 3-8. [CrossRef] [PubMed]

47. Sheldrick, G. Crystal structure refinement with SHELXL. Acta Crystallogr. C 2015, 71, 3-8. [CrossRef] [PubMed]

48. Dolomanov, O.V.; Bourhis, L.J.; Gildea, R.J.; Howard, J.A.K.; Puschmann, H. OLEX2: A complete structure solution, refinement and analysis program. J. Appl. Crystallogr. 2009, 42, 339-341. [CrossRef]

49. Farrugia, L. WinGX and ORTEP for Windows: An update. J. Appl. Cryst. 2012, 45, 849-854. [CrossRef]

50. Spek, A. CheckCIF validation ALERTS: What they mean and how to respond. Acta Crystallogr. Sect. E 2020, 76, 1-11. [CrossRef]

51. Macrae, C.F.; Bruno, I.J.; Chisholm, J.A.; Edgington, P.R.; McCabe, P.; Pidcock, E.; Rodriguez-Monge, L.; Taylor, R.; van de Streek, J.; Wood, P.A. Mercury CSD 2.0 - new features for the visualization and investigation of crystal structures. J. Appl. Crystallogr. 2008, 41, 466-470. [CrossRef]

52. Frisch, M.J.; Trucks, G.W.; Schlegel, H.B.; Scuseria, G.E.; Robb, M.A.; Cheeseman, J.R.; Scalmani, G.; Barone, V.; Mennucci, B.; Petersson, G.A.; et al. Gaussian 09. Gaussian, Inc.: Wallingford, CT, USA, 2009.

53. Sciortino, G.; Maréchal, J.-D.; Fábián, I.; Lihi, N.; Garribba, E. Quantitative prediction of electronic absorption spectra of copper(II)-bioligand systems: Validation and applications. J. Inorg. Biochem. 2020, 204, 110953. [CrossRef]

54. Tomasi, J.; Mennucci, B.; Cammi, R. Quantum Mechanical Continuum Solvation Models. Chem. Rev. 2005, 105, 2999-3094. [CrossRef]

55. Yanai, T.; Tew, D.P.; Handy, N.C. A new hybrid exchange-correlation functional using the Coulomb-attenuating method (CAM-B3LYP). Chem. Phys. Lett. 2004, 393, 51-57. [CrossRef]

56. Chai, J.-D.; Head-Gordon, M. Systematic optimization of long-range corrected hybrid density functionals. J. Chem. Phys. 2008, 128, 084106. [CrossRef]

57. Krukau, A.V.; Vydrov, O.A.; Izmaylov, A.F.; Scuseria, G.E. Influence of the exchange screening parameter on the performance of screened hybrid functionals. J. Chem. Phys. 2006, 125, 224106. [CrossRef]

58. Tao, J.; Perdew, J.P.; Staroverov, V.N.; Scuseria, G.E. Climbing the Density Functional Ladder: Nonempirical Meta-Generalized Gradient Approximation Designed for Molecules and Solids. Phys. Rev. Lett. 2003, 91, 146401. [CrossRef] 
59. Zhao, Y.; Truhlar, D.G. A new local density functional for main-group thermochemistry, transition metal bonding, thermochemical kinetics, and noncovalent interactions. J. Chem. Phys. 2006, 125, 194101. [CrossRef]

60. Boese, A.D.; Handy, N.C. New exchange-correlation density functionals: The role of the kinetic-energy density. J. Chem. Phys. 2002, 116, 9559-9569. [CrossRef]

61. Becke, A.D. Density-functional exchange-energy approximation with correct asymptotic behavior. Physical Review A 1988, 38, 3098-3100. [CrossRef]

62. O'boyle, N.M.; Tenderholt, A.L.; Langner, K.M. Cclib: A library for package-independent computational chemistry algorithms. J. Comput. Chem. 2008, 29, 839-845. [CrossRef] 